\title{
Judíos, conversos y judeoespañol. Apuntes históricos
}

\author{
Juan Antonio Frago* \\ Universidad de Zaragoza, España
}

\begin{abstract}
Resumen
Se aborda en este artículo la historia del judeoespañol, desde sus raíces peninsulares a la nivelación que experimentó la diversidad lingüística de los judíos desterrados. Asimismo se tiene en cuenta la cuestión de los conversos de última hora y de generaciones de cristianos nuevos, pues son quienes en declaraciones inquisitoriales, como acusadores o acusados, aportan datos sobre su realidad cultural e idiomática, asimismo ilustrativa de la que en las juderías se vivía, y porque de ellos durante mucho tiempo hubo exilios provocados por la tenaz presión de la Inquisición. Se incluye el estudio de una comunidad hebrea de Aragón, por el peso que en la diáspora tuvieron los de procedencia rural y como ejemplo de lo que eran las juderías grandes y chicas en 1492. Finalmente, se relacionan las hablas sefarditas con el verdadero tablero lingüístico de España a finales del siglo $\mathrm{XV}$, visión documental que justifica su formación y permite afirmar que, en efecto, existió un judeoespañol, al menos en fundamentales aspectos, antes de que se firmara el Edicto de expulsión.
\end{abstract}

* Para correspondencia, dirigirse a: Juan Antonio Frago (jafrago@unizar.es), Universidad de Zaragoza, Paseo de las Damas, 44, $2^{\circ}$ izda, 50008 Zaragoza, España. 
Palabras clave: lengua y cultura de judíos y conversos, una judería rural en la expulsión, la base lingüística del siglo XV, judeoespañol peninsular y de la diáspora.

JeWs, CONVERTS AND JudeO-Spanish. Historical nOteS

\begin{abstract}
The history of Judeo-Spanish is addressed in this article, from its peninsular roots to the levelling experienced by the linguistic diversity of the exiled Jews. The question of last minute converts and generations of new Christians is also taken into account, since they are the ones who in inquisitorial statements, as accusers or defendants, provide data on their cultural and idiomatic reality, as well as illustrative of the life in the Jewish quarters, and because of them for a long time there were exiles provoked by the tenacious pressure of the Inquisition. It includes the study of a Hebrew community of Aragon, due to the weight that those of rural origin had in the diaspora and as an example of what were the big and small Jewish quarters in 1492. Finally, the Sephardic speech is related to the real linguistic board of Spain at the end of the 15th century, documentary vision that justifies its formation and allows to affirm that, indeed, a Judeo-Spanish existed, at least in fundamental aspects, before the Edict of expulsion was signed.
\end{abstract}

Keywords: Jews and converts language and culture, a rural Jewish quarter rural in the expulsion, the linguistic bases of the 15th century, peninsular Judeo Spanish and the diaspora.

Recibido: 27/12/18 Aceptado: 04/03/19

\title{
1. CUESTIONES PRELIMINARES
}

\subsection{El 1492, UN JALÓN HISTÓRICO}

1.1.1. La toma de Granada supuso la eclosión de un fervor castellanista que llevó aparejada la exaltación del sentimiento de unidad nacional, faltaba la próxima incorporación de Navarra para lograrla en el plano territorial, algo claramente manifiesto en la composición cancioneril de Pedro Marcuello, "y es cierto quel bien ha España / de Castilla nos venía", un aragonés para 
quien el castellano era "nuestra lengua", aun con "los dichos aldeanos" con que la empleaba (Marcuello 1987: 23, 48). El impacto social que tuvo el final de la Reconquista fue tal, que en los últimos años del siglo XV y primeros del XVI se advierte un rápido abandono del característico aragonés notarial por el castellano, ambos indistintamente usados por el escribano público rural Antón Francés, a cuyo protocolo pertenece el legajo aquí expurgado (v. n. 11). Esa mítica fecha efectivamente marca el rápido declive del aragonés escrito, y la castellanización se intensifica notoriamente en los principales centros urbanos, lo que, por ejemplo, demuestran los documentos municipales de Zaragoza, que durante todo el siglo XV habían mostrado un creciente deterioro del idioma vernáculo, llegándose así a la situación que a Nebrija le permitió afirmar: "la cual [lengua castellana] se estendió después hasta Aragón e Navarra, e de allí a Italia, siguiendo la compañía de los infantes que embiamos a imperar en aquellos reinos" (Nebrija 1492/1980: $100)^{1}$, situación que estaría más consolidada cuando Valdés c. 1535 advertía: "porque como la lengua castellana se habla no solamente por toda Castilla, pero en el Reino de Aragón...". (Valdés 1969: 62)

Cierto, pues, que Nebrija al referirse lingüísticamente a Aragón tendría en cuenta el habla de los cultos, y sin duda también Valdés, más aún en el caso de Galicia, pues a ciencia cierta sabemos que en esta región la masa popular durante el siglo XVI en su gran mayoría era monolingüe, e incluso entre no pocos individuos de la clase dominante el bilingüismo era imperfecto. Documentalmente lo certifica Maia (1997: 900-901), y que, a pesar de la creciente influencia del castellano en la lengua escrita, este fuera el panorama lingüístico del noroeste peninsular lo corroboran noticias y comentarios de sefardíes en la diáspora, que continuaban formando parte del cuerpo lingüístico hispano. En efecto, en judeoespañol gayego es 'individuo de lenguaje pobre', y los originarios de esta región se tenían por primitivos, con frecuencia grupo aparte en las comunidades importantes de judíos de Oriente, habiéndose acuñado dichos como Semos gayegos, no vos entendemos, Semos gayegos, no mos entendemos, Ónde estamos, ¿a Gayegos? (Nehama 1977: 226)

La caída de Granada dio alas al proceso castellanizador en general, por el impacto nacional e internacional que tuvo, constancia hay de la participación

\footnotetext{
Es claro que "aquellos infantes que embiamos a imperar en aquellos reinos", a los que Nebrija alude, de la Corona de Aragón eran, y que Alfonso el Magnánimo en castellano hablaba y escribía, como los poetas aragoneses de su humanística corte napolitana, pues aún no habían comenzado las contiendas entre franceses y los españoles del Gran Capitán para que el influjo directo de Castilla se diera.
} 
de extranjeros en las huestes cristianas, ingleses y suecos entre ellos, hecho que conmocionó a judíos y moriscos, hasta el punto de que el Mancebo de Arévalo, mitificando a Andalucía como una "nueva Israel", entendió que ambas habían caído por castigo divino de sus pecados (Narváez 1981:143). Y la documentación de la empresa militar de los Reyes Católicos también arroja luz sobre aspectos lingüísticos de las comunidades judías en territorio aún musulmán, pues el aragonés Juan de Coloma, sobre el que más adelante habré de volver, el 24 de marzo de 1488 expide salvoconducto en castellano a favor de un judío granadino, su mujer e hijos para que pudieran pasar al lado cristiano, asegurándoles libertad y plena posesión de sus bienes (De la Torre 1951: $57-58)^{2}$. Cuatro años después, paradojas de la historia, el mismo secretario real un 31 de marzo corroboraría notarialmente y redactaría el implacable Edicto de expulsión.

1.1.2. De modo que el año 1492 jalonó historias de larga trascendencia, pues de un lado culminaba el multisecular proceso reconquistador, ocasión para la heterogénea repoblación del sureste peninsular, de la que saldría un romance de varios perfiles dialectales, dominante el bético, con el resultado final de la variedad oriental del andaluz, que cerraba el escenario lingüístico del español peninsular. De otro lado, y mientras se estaba fraguando la variedad dialectal canaria, el 17 de abril se firmaban las Capitulaciones de Santa Fe, que abrirían el camino hacia el más anchuroso horizonte de nuestra lengua. Tan prometedor acuerdo lo conformaba y suscribía notarialmente el mismo protonotario aragonés que días antes había sellado un decreto real de tan contrario sentido, conminatorio de la expulsión de los judíos hasta el fin fieles a su religión, probablemente limitando así posibilidades al progreso de España, aparte de lo tremendamente injusta que semejante disposición era. La amputación demográfica que la perentoria orden causó supondría la formación y consolidación del judeoespañol en la diáspora, aunque ya el siglo XIV había conocido la partida de muchos judíos españoles a Portugal y otros países europeos, en buen número también al norte de África y Tierra Santa. La sangría migratoria en distintas proporciones numéricas seguiría durante mucho tiempo al 1492, consecuencia de la tenaz persecución inquisitorial contra los conversos y sus descendientes, situación que el ideario popular plasmó en la paremia No fies del judio converso, ni de su hijo ni de su nieto

\footnotetext{
2 Al pie del texto castellano se anota: "Quatuor similes fuerunt expedite sub eiusdem kalendario, forma et signatura et mandato, in albo".
} 
(Martínez Kleiser 1982: 295)3. Del realismo sociológico de este refrán es palmaria prueba la real cédula del 12 de febrero de 1556 sobre prohibiciones migratorias hacia América:

Ordenamos que ninguno nueva mente conbertido a nuestra sancta fe, de moro o de judio ni hijo suyo, pueda pasar ni passe a las dichas nuestras Indias si no muestra especial licencia, y ansimismo defendemos y mandamos que ningún reconçiliado ni hijo ni nieto del que públicamente obiere traído sambenito, ni hijo ni nieto de quemado o condenado por ereje por delicto de la herética pravedad, por línea masculina ni femenina, pueda passar ni pase a las dichas Yndias ${ }^{4}$.

\subsection{UN CRISTIANO NUEVO ARAGONÉS HUMANISTA Y SU EJEMPLO LINGÜÍSTICO}

1.2.1. Obligada atención merece en este punto la figura de micer Gonzalo García de Santa María, de famosa estirpe de conversos castellanos, fundada por el sabio rabino burgalés Salomón Haleví, bautizado el año 1390 con el nombre de Pablo de Santa María, que llegaría al episcopado, a la cancillería real y a ser tutor de Juan II, de cuyo reinado fue cronista su hermano Álvar, regidor de Burgos y poseedor de cuantiosa fortuna. Las dudas que algunos estudiosos parecen tener sobre el origen de este personaje, las despeja el antijudaico libelo aragonés: "Del linage de los Levís judíos de Soria del reyno de Castilla fue uno que se convirtió con su muger, que le dijeron Thomás García de Santa María, hermano del obispo don Pablo de Burgos", uno de cuyos hijos fue Gonzalo García de Santa María, mercader, "el qual había sido judío y siendo muy pequeño se había baptizado con su padre", a su vez progenitor de nuestro micer Gonzalo García de Santa María, que "fue casado con Violante de Velviure, conversa valenciana" (De las Cagigas 1929: 18, 48). De relevancia social y bienes de fortuna, cercano a Fernando el Católico, lo que ni a él ni a su mujer les evitó dolorosos tropiezos con la Inquisición, usaba un excelente castellano, aunque mezclado de algunos aragonesismos, igual que todos los escritores aragoneses de la época. Pero de este personaje particularmente es destacable que de primera mano

\footnotetext{
Los refranes de esta obra referidos a la figura del judío, nada menos que 102, se citarán sin página, mención que solo tendrán los sacados de otras fuentes.

4 BNE, Ms. 3045, 157r. Esta provisión real se pregonó en la plaza de Pasto (Popayán) el 6 de julio de $1556(158 \mathrm{v})$. Aunque desde antes, y aun después, se promulgaron otras cédulas de semejante tenor, prueba de su escasa efectividad, nula en algunos casos.
} 
conociera la doctrina del humanista italiano preferido en la corte napolitana de Alfonso el Magnánimo, al menos en "dos volumes de obras de Lorenço de Valla, en paper, de mano" de su riquísima biblioteca (Serrano y Sanz 1914: 475), que adapta a la situación española de su tiempo con el aliento del providencialismo judío y defensa de la monarquía absoluta.

Efectivamente, en el prólogo de Las vidas de los sanctos padres religiosos (c. 1490-1491), anticipándose a Nebrija y de manera más elaborada que el insigne humanista andaluz, presenta la idea de la lengua "compañera del imperio" modificando el contexto histórico y político en que Valla la formuló, ampliando y matizando el sentido que imperio tiene en la expresión nebrisense "que siempre la lengua fue compañera del imperio..."; en su Prohemio a los Reyes Católicos Juan del Encina escribiría: "y porque lo que es de César se dé a César, quise primero darles la obediencia de este mi trabajo con la vmildad y acatamiento que devo, suplicándoles si algo bueno huviere, estimando cada caso en su estado, lo manden favorecer y lo malo corregir, pues a los príncipes y emperadores conviene tener debaxo de su imperio assí malos como buenos" (1496/1989: 1r) $)^{5}$. El jurisperito aragonés, partiendo de la preeminencia de Castilla, "porque el real imperio que oy tenemos es castellano", y de su convencimiento de que "la habla comúnmente más que las otras cosas sigue al imperio", juzga que "en cada lugar es avida la lengua de la corte por de todas la mejor y más encimada..., como piedra de toque de todas las otras lenguas de la tierra", y la Corte aún no tenía sede fija en la época.

1.2.2. Cree García de Santa María en el gran influjo de la que andando el tiempo se llamaría "norma cortesana", porque en ella se reunía "la gente de consejo y letrados y embaxadores", y "los que hablan delante de los reyes y príncipes trabajan de poner sus buenas razones por los mejores términos que saben y alcançan", además de que "el vocablo deve ser como la moneda, de tan buena liga, peso y cuño, que en ninguna tierra de las mismas del príncipe que la batió se rehuse". Considera también que "la misma differencia y ventaja que lleva la habla del hombre de pro a la del villano y soez, aunque ayan ambos nascido en una misma ciudad y barrio, aquella lleva la de la corte a la de las otras villas y ciudades de todo el reyno", en importante aspecto coincidente con lo que hacia 1307 Dante Alighieri había notado

\footnotetext{
5 Como Asensio advirtió (1960:400-401), deriva de las Elegantiae de Valla "la máxima afortunada, que Nebrija acuñó", concepto que "había sido resumido en frase muy parecida por el jurista aragonés Gonzalo García de Santa María antes de hallar hospedaje en las páginas de Nebrija".
} 
en los dialectos italianos, ejemplificando en Bolonia la variación social del habla, "ut Bononienses burgi Sancti Felicis et Bononienses Strate Maioris" (1982: 48); y micer Gonzalo rechaza el arcaísmo, pues "lo muy antiguo" de la lengua "es tan áspero y rudo, que se debe el hombre de tal antigüedad guardar", dando un paso adelante en la determinación de la geografía lingüística hispana sobre la temprana y oportuna glosa de Mosé Arragel, rabino de Guadalajara, en su traducción de la Biblia de Alba (entre 1422 y 1433):

E bien asy como oy día en un singular regno la lengua en los omnes egual non es, conviene saber, por las letras o por modos (sylabas) de órganos. Bervigracia, en Castilla sean cognoscidos leoneses e sevillanos e gallegos. E aunque en parte quieran por vía de descognocimiento fablar vocablos e motes qualque, tantos ende averá que ninguna destos cambiar non podrá, por onde de nescesario cognoscidos son ${ }^{6}$.

Para el jurista aragonés, ya con mayor precisión diatópica: “ay allende esso en la misma Castilla, como son diversos reynos en uno ayuntados, algunas tan grosseras y ásperas lenguas como es Galizia, Vizcaya, Asturias y Tierra de Campos, que ni aquellas ni lo muy andaluz es avido por lenguaje esmerado"7. La atención del judío a la diversidad de lenguas, y a su misma variación interna, es de larga tradición, ya desde el episodio bíblico de la

6 Cita abreviadamente este pasaje Menéndez Pidal (1962: 111), e íntegro con referencia al dialecto meridional hispalense, "los sevillanos presentaban características fónicas y léxicas que permitían identificarlos como tales", González Ollé (1987: 349); sobre el sabio rabino y su traducción bíblica véase Baer (1981: 509-510, 764). De no poco interés es el estudio sobre la Biblia de Alba de Morreale, en cuya preliminar "Tabla por a.b.c.", para la mejor comprensión del texto bíblico traducido (1961: 145-148), esta estudiosa señala casos de metátesis (plorixo 'prolijo', plórogo 'prólogo'), de adición o pérdida consonántica (pular 'plural', pularidad), de inflexión y aun de 'anarquía de las vocales' (fillycidat, ductrina, humilía, blesphamio, redemir, sologismo, superfaçio), de reducción del diptongo (olocastia 'holocaustia'). A esa inestabilidad le añade la influencia de "ciertas inflexiones vocálicas" del hebreo, "y sobre todo por la asibilación de formas como çoçiedad, çuçitar", y que Ción por Sión "podría tomarse como símbolo de los textos bíblicos y de devoción en uso entre judíos aun antes de salir de España". Advierte Morreale que la apócope de "al mortal dolient" le corresponden apócopes más tajantes de la Biblia de Ferrera y rituales latinos impresos desde el XVI, como crián, matán, además de registrar casos como habuminación, afermosiguar, abeviguar, alsación 'sacrificio', aublación junto a jubilación, oinar 'lamentar', sonbajar 'engañar', tempración 'libación', egleja 'iglesia', doladicio 'ídolo', profundina.

7 La referencia de micer Gonzalo a "lo muy andaluz" en Asensio se identifica exclusivamente con lo "muy morisco", es decir, con el arabismo léxico, pues según él "Andalucía, infestada de términos moriscos y ajenos al resto del país, no puede competir con Toledo", transfiriendo así el problema dialectal real al manido tópico de la "norma toledana" (1960: 404). Pero sabido es que en Aragón y Valencia había mucho más de "morisco" que en 
Torre de Babel al de la lucha entre galaaditas y efraítas, con la distinción del sibolet, que tendría imitación hispana tanto en la Península como en América, según este pasaje del cap. 12 de Jueces en la Biblia de Ferrara (Lazar 1996: 420-421):

Y prendió Gilhad a passages del Yarden a Ephraim; y era quando dezían: escapadizos de Ephraim, passaré; y dezían a él varones de Gilhad: ¿si Ephrateo tú? Y dezían, no. Y dezían a él: di agora Sciboleth. Y dezían Siboleth; y no acertava para hablar assí, y travavan a él, y degollávanlo a passajes del Yarden; y cayó en la hora essa de Ephraim quarenta y dos $\mathrm{mil}^{8}$.

Era, pues, micer Gonzalo novedoso en su referencia al andaluz, revestido de atributos humanísticos por su atención a la lengua materna, consciente de sus valores políticos y sociológicos, y precedente de la idea de la normatividad atrapado por la lectura, rasgo renacentista que poco después sublimaría Maquiavelo (2012), como asiduo y emocionado lector que fue de los clásicos, conocedor también del citado tratado romanístico de Alighieri, y con semejante visión de su vulgar a la de García de Santa María. Y no estará de más tener en cuenta que, aun cuando Juan de Valdés niega haber leído "las Vidas de los Padres que compuso san Gerónimo" (1969: 168), algo poco creíble dado el éxito editorial que hasta su prohibición en 1559 esta obra tuvo, en él se percibe el eco de las principales cuestiones consideradas por micer Gonzalo.

1.2.3. La lengua de García de Santa María es la expresión culta de su variedad regional, como sus particularismos tuvieron autores cultivados de otras regiones españolas, en la antesala del escenario lingüístico del quinientos, en un ambiente que con transferencia indiana denotan estos versos de Eugenio de Salazar (Benítez 1962: 60):

\footnotetext{
Andalucía occidental, donde, entre otras razones, se había producido una numerosa migración musulmana al vecino reino de Granada.

8 Covarrubias (1611/1979: 397) en su definición de cecear trae este episodio bíblico, pero con grafía schibbolet de la primera voz, cuya sch-inicial desvía la realidad del contenido fonético en cuestión -su texto latino trae scibolet- que el sabio canónigo distinguió bien en su comentario: "como nosotros conocemos los que son moriscos con hacerles pronunciar cebolla, y ellos dicen sebolla". Se refiere el erudito canónigo a una artimaña que al parecer se practicó en la guerra de las Alpujarras para descubrir al morisco disfrazado de cristiano, como en las guerras de la independencia de América en ocasiones la palabra Francisco sirvió para conocer a los realistas, lo que en opinión de Guitarte "viene a confirmar el carácter de sibolet que tenía el seseo". (1983: 107-109)
} 


\begin{abstract}
Gramática concede sus entradas a la ingeniosa puericia nueva que al buen latín sus galas ve inclinadas: gusto del buen hablar tras sí las lleva del lenguaje pulido y bien sonante y en el buen escribir también se prueba.
\end{abstract}

Es el castellano de su coetáneo Juan de Coloma, secretario preferido de Fernando el Católico y protonotario de Isabel la Católica, y el de Felipe Climente, hijo de Mosé Chamorro, judío de Zaragoza convertido al cristianismo, también secretario real, que en sus escritos curialescos desliza la grafía aragonesa $n y$ de la palatal nasal (danyo, senyores), igual que Coloma en el Edicto de expulsión (atanye, atanyer), con otros aragonesismos (De la Torre 1962: 173-174, 213). Como muy letrado y del buen hablar y escribir fue Alfonso de la Caballería, miembro de poderosa familia de conversos zaragozanos, vicecanciller de Aragón y "el más famoso jurista y político de su tiempo", o Gabriel Sánchez, tesorero general del rey y su hermano Luis, de quien había heredado puesto de tan alta responsabilidad e influencia, nietos de Isac Golluf, que apostató con el nombre de Juan Sánchez de Calatayud, meses después del fallecimiento de su padre Alazar (agosto de 1389), importante personaje en la corte de Juan $\mathrm{I}^{9}$.

1.2.4. Por cierto, un clérigo catalán declaró en 1485 que, estando en la corte real de Córdoba, vio a Alfonso de la Caballería y a Gabriel Sánchez conversando con rostros de preocupación dos meses antes del asesinato del inquisidor Pedro de Arbués, de cuya preparación fueron sospechosos, y de hecho Gabriel y Luis Sánchez habían demandado "a cierto R. Manuel ben Aljoar de Magallón que pidiera por ellos a las estrellas y les escribiera conjuros hebreos" (Baer 1981: 601). El 28 de septiembre de 1486 "Rabí Manuel, judío vezino de la villa de Magallón", como testigo en proceso inquisitorial juró "que oyó decir a Simón de Sancta Clara de Calatayud muchos vituperios contra la fe cristiana y comparava a la virgen María con la torhá, diziendo este verso en ebrayco: acol taluy bematizal afitlu 'sancta María en el altar"' (López Asensio 2016: 507). Su fama de astrólogo, y de que tanto escribía en hebreo como en romance, lo llevó a la oscense Ayerbe,

\footnotetext{
9 Baer (1981: 352, 377-378, 563, 603). La riqueza de Gabriel Sánchez llegó a tal extremo, que su soberbio palacio sirvió para dar nombre a la calle en que se había construido (Carrera de don Artal de Alagón, alias del Tesorero Sánchez), para Fernando el Católico "muy gran jaula para tan pequeño páxaro". (Sesma Muñoz 1992: 157-159)
} 
donde estuvo "hun rabí llamado Manuel, y saquava libros en christianego para la Señora" del lugar, quien le pidió "que le saquasse del Salterio la Flor de los salmos y oraciones". (Sesma Muñoz 1992: 433)

De este personaje, muy curioso por su saber astrológico y dominio de las dos lenguas, hay constancia de su presencia en Zaragoza, llamado por el converso Bartolomé Sánchez, deseoso de saber si era buena la elección matrimonial pensada para su hija, con petición de que le escribiera un "iudicio" sobre este asunto. Y tal vez por entonces, hacia 1482, recurrió a él micer Jaime de Montesa pidiéndole si podía transmitirle, siendo él cristiano, "aquel arte que él conocía de devinar", a lo que el rabí Manuel le respondió que no, "sino que hubiese de saber el ebrayco y supiese la biblia y aquellos motes de obra y de cura", rogándole luego el cristiano nuevo que "levantase iudicio que qué sería de su fija et con quién casaría et... de los oficios de la ciudad y del rey, cómo lo quería", lo que el rabino de Magallón compuso con sus textos (Marín Padilla 1983: 267-268) ${ }^{10}$. Se documentará su presencia en la judería de esta pequeña población en los meses precedentes a la amarga hora de la expulsión, hasta la que llegó firme en su ley, actuante en la liquidación de los bienes de su pertenencia y en la de los más caros a la aljama (baños y sinagoga), con mención textual de su núcleo familiar.

\section{UN MICROCOSMOS JUDÍO EN ARAGÓN}

2.1. Esta localidad del Aragón medio occidental se halla a poco más de treinta kilómetros del linde castellano por Tarazona, y a unos once de la villa Navarra de Cortes ${ }^{11}$. Su judería, como tantas otras del reino, no era de gran entidad demográfica, de mayor número, sin embargo, que los 110 a 130 miembros que se le asignan, enclavada en un dominante medio rural, pero

10 Consta que el 27 de septiembre de 1485, el Rabí Manuel estaba "de present" en la villa de Magallón y que conoció que micer Montesa tenía "afección a su ley e inclinación a ella" (ibídem).

11 Los datos manuscritos aquí expurgados son del archivo municipal de Magallón (Zaragoza), caja 181, legajo del protocolo de Antón Francés. Desde el folio 42v son los textos relativos a la liquidación de bienes antes de la expulsión, de los que, salvo contadas transcripciones, alguna total y varias parciales, resume en regestas Motis Dolader (1984). Los manuscritos anteriores, que cubren los primeros meses de 1492, no han sido estudiados, y el conjunto de dicho legajo se tiene aquí en cuenta en todos sus originales. 
que en este y otros aspectos guarda semejanzas con las comunidades hebreas más importantes de Aragón y de Castilla, estando atestiguado el oficio campesino en individuos de la aljama de Zaragoza, donde "ambos judíos, los Morçones, son unos labradores de junto a Santa Engracia" ( $L V A, 68)$. Nada extraño, si Baer tiene en cuenta las "tierras que poseían y trabajaban los judíos de Aragón en la segunda mitad del siglo XIII", y que "a los judíos de Borja todavía en 1459 se les acusaba de que se llevaban a sus casas en secreto la cosecha de sus campos ("fruges, linum et canapum") y sus ovejas y cabras, para no pagar los diezmos y primicias que le correspondían a la Iglesia", además de que "sin duda vivían de la agricultura" los que estaban aislados en ciertas aldeas (1981: 710-711) ${ }^{12}$.

Así, pues, aunque no hay explícita constancia de esa dedicación personal al trabajo del campo de los judíos de Magallón en sus propiedades agrarias, no parece improbable, y desde luego el aprovechamiento agrícola aparece en ventas como la que Yentó Farag hace a un cristiano de "unas casas suyas sitiadas en la dita judería", además de "hun malluelo... e dos cubas e dos caxas de pino e nogera" (61v), o en la de Mosé Atortox de casas que posee en el entorno del castillo, con "dos cilleros oliarios" (64r); Jacó Çaruch liquidaría otra vivienda con "bodegas vinarias" (72r). El mismo judío también haría otra venta de casas con otro cillero y dos cambras pequeñas adosadas (83r), y desde luego los productos del campo serían objeto de comandas y diversos trueques, verbigracia el de cinco cahices de trigo que se hace con el vecino de esta localidad Pero Francés (78v).

Comoquiera que sea, el capítulo agrícola fomentó el trato de judíos con cristianos y moros, lo que sin lugar a dudas prueban los documentos de liquidación de bienes de esta judería ${ }^{13}$, y esas relaciones entre religiones y razas tienen sus consecuencias lingüísticas, que en el afán campesino se darían casi cotidianamente, igual que las fomentadas por otras actividades lucrativas. De oficios que tengan que ver con lo mercantil solo se registra el del rico mercader Salomón Atortox, también dedicado al préstamo, con negocios en varias localidades aragonesas y en Valencia; Abram Oficial se menciona como sastre y tejedor en texto anterior a la expulsión, asimismo dedicación artesanal de Jucé Altexofi, y tundidor (tondidor) era un Açach de

12 Frente a lo expuesto por Baer, taxativamente afirma Motis Dolader que "los judíos no se dedican profesionalmente a la agricultura -estos no son labradores stricto sensu-, pero sí rentabilizan los predios de su propiedad". (1992: 145)

13 De su detalle económico y de la cuantificación de sus bienes urbanos y rurales, así como de los niveles dinerarios de sus integrantes, se ocupa Motis Dolader (1986). 
Leví, así nombrado el 17 de febrero de 1492 (22v), que no aparecerá en los escritos notariales movidos para el destierro. Muy pocos nombres de oficio, en todo caso, los referidos entre el 30 de noviembre de 1491 y el 18 de julio de $1492^{14}$, lo que tampoco significa que los demás miembros de la judería de Magallón se dedicaran a la agricultura, dado que tales documentos son de sucinta redacción, hasta tres puede haber en algunas páginas del legajo. Es en los procesos inquisitoriales, sobre todo en su parte de interrogatorio, donde acusados y testigos extreman la minuciosidad identificativa, atendiendo a cualquier detalle sobre la persona del acusado, lo que los hace inestimable fuente para el conocimiento de las profesiones que desempeñaron judíos y conversos, en Aragón y en los demás dominios peninsulares ${ }^{15}$.

2.2. La misma onomástica arroja luz sobre variados aspectos de la vida en las comunidades judeo-peninsulares y de la dramática conversión de muchos de sus miembros, con duradera repercusión en quienes querían ocultar su pasado familiar para evitar la estigmatización social y el peligro del acechante Santo Oficio. Algo sobre lo que hacia 1575 aún llamaría la atención de Orozco, quien recordaba lo que a los confesos de Toledo supuso que en 1538 se mandara colgar los sambenitos en las iglesias donde sus antepasados habían sido parroquianos ${ }^{16}$. El apellido Trigo era el de un famoso médico, Junez Trigo, de Zaragoza, también comerciante en telas y dueño de tierras de cultivo, con su familia merecedor de elogios y prebendas reales a finales del siglo XIV (Baer 1981: 349-350); antes, en 1331, ya figura un "Açahc Trigo, fillyo de don Açahc", miembro distinguido de la aljama zaragozana (Tilander 1958: 43); y en la de Magallón a las puertas

14 En cambio, la junta de la aljama de moros del vecino lugar de Bureta, convocada el 21 de enero de 1492 (11v), en una sola plana registra los oficios de albañil (alvañir), carnicero, corredor, ferrero, zapatero. Esto, aparte de lo que lingüísticamente supone la presencia en el mismo texto de los apodos o apellidos Hamet el Pájaro, Jucé Cavallero y Jucé Palomino.

15 Sin pretensión de exhaustividad extraigo este recuento onomástico de los corpus Judioconversos y LVA: aguardentero (auguardentero), apotecario, calcetero, cambiador, cedacero, cirujano, contador, cordonero, corredor, costurera, especiero, jubonero, labrador, lencero, lezdero, maestro de casas (y obrero de casas), médico (y mege), mercader, pañero, pellero (y pelletero), pintor, platero (y argentero), recadero, ropavejero, sastre, tañedor de laud, tejedor, trapero (y traper), vinatero, volteador, zapatero (y çabater), zumaquero.

16 "E por esto todos o los más se han quitado y mudado los nombres antiguos que tenían de sus agüelos y antepasados, que ya en esta çibdad no se hallarán quien de aquellos nombres y apellidos antiguos de confessos se llame, así como Fagueles, Guaypanes, Garayres, Golondrinos, Husillos, Jaradas, Cotas, Cañamones, Alixandres, Hametes, Hayetes, Dientes, Falos, Cabales, Atres, Pabones, Talayes, Tardones...”. (Orozco 1981: 111) 
de la expulsión vivía Jaccó Çaruch Trigo, asimismo anotado como “Jaccó Çaruch alias Trigo" (78v, 83r), término romance al que como mote o como nombre de familia tanto apego tuvieron los judíos. Trigo sería el de Roma en La Lozana Andaluza, un sefardita literario, nombre familiar del que algunos conversos no quisieron abdicar, como demuestra esta mención: "Joan de Altavás, pintor, era muy propinquo de judío y casó con Joana Trigo, que havía sido judía". (LVA, 71)

Dicho antropónimo muestra la familiaridad lingüística de la judería con la circunvecina "cristiandad", igual que el nombre de familia Albo de la mujer de Alaçar Arruetí, Ezter Albo (84r), latinismo que también llevó el famoso R. Yosef Albo, delegado de la aljama de Daroca en la disputa de Tortosa (Baer 1981: 445); pero son más las referencias que la onomástica de la aljama de Magallón aporta de cruces lingüísticos condicionados por la contigüidad e interrelación de ambas comunidades, judía y cristiana. En efecto, Aljonar del Portillo era "muller del dito Açach Gallar" (18v), Cinfa Pérez, de Simuel Arruetí, y Yentó Çaruch Pérez, hijos de Elissa Çaruch Pérez (78v), apellido de arraigo en esta villa (v. n. 19); como Duenya Amillo y Duenya Benforna se nombra a la "vidua de Salamón Benforna" (66v, $72 \mathrm{r})$. Otros miembros de la judería eran Salamón Pérez (45v), Salamón de la Rasa (53r-v) y Jucé Çaruch Franco, cuyo sobrenombre romance tal vez refiera a su condición de 'libre de impuestos', testigo en una venta de trigo de Mossé Atortox (28r). Incluso la mujer del Rabí Manuel, que aparece como Soli en tres ocasiones (61r, 68r, 70r), pero como Soli de Solinas en acto público de "fadiga" del 25 de enero, por el que ella, su marido y Mayl Manuel, "fillo del dito Rabí", se comprometían a no enajenar "hun guerto dellos sito al banyo de los jodíos... sin que primero fuese dada la fadiga de aquello a Jucé Çaruch". (13v)

La judería de Magallón contó con los gentilicios ultrapirenaicos gascón (Jucé Gascón, Salomón Gascón) y francés (Jucé Francés, Jucé Francés Çaruch o Jucé Çaruch Francés ${ }^{17}$. En la aparición de tales antropónimos en muchas comunidades hebreas del Aragón Medio, pudo influir la temporal expulsión que los judíos sufrieron en Francia en $1182^{18}$, así como las

17 También sería ultrapirenaico el romance gento 'gentil, gallardo', que asimismo se hizo apellido de hispanos y probablemente también de algunos hebreos $(D E C H)$. En los documentos de la expulsión de Magallón el nombre hebreo Gentó tiene un registro y es constante con y-en todas las demás menciones de Yentó Açamel, Yentó Çaruch Pérez, Yentó Farag, Yentó Gito, Yentó Leví y Yentó Oficial. Jentó Auenjuha y Gentó Auenbitas eran de la aljama zaragozana en la primera mitad del XIV (Tilander 1958: 10).

${ }_{18}$ El estudio de la onomástica judía en todas sus posibles relaciones con la fonética romance, así por referencia a la antecedente variación Gentó-Yentó, requiere la cooperación 
siguientes medidas punitivas que se les acordó, o las hirientes controversias religiosas vividas en el mediodía francés en la primera mitad del siglo XIII, con repercusión en las aljamas de la Corona de Aragón (Baer 1981: 80-87), aunque su causa principal tal vez pudo ser la intensa repoblación de este Reino procedente del sur de Francia y el activo papel comercial desempeñado en él por gentes ultrapirenaicas. Ocurre, además, que iguales gentilicios llevaban cristianos de dicha villa, en los mismos escritos de expulsión de un lado Joan Gascón, Miguel Gascón, y de otro el propio notario que los validó, Anthón Francés, además de Joan Francés, Pero Francés y “mossén Miguel Francés, clérigo de la dita villa" (61r), todos ellos como testigos o intervinientes en los tratos y contratos económicos, con alguna coincidencia tan extraordinariamente llamativa como la que se da en uno de los últimos actos notariales que se hicieron el 17 de julio, atestiguado por "Joan Francés e Jucé Francés, jodío de la dita villa". (90r)

En el registro de bautismos de los Quinque Libri, que en esta localidad se inicia el año 1549, consecuencia del Concilio tridentino, abundan los apellidos Gascón y Francés ${ }^{19}$, y no sería extraño que en algún caso pudiera haber existido precedencia familiar conversa, pues el apego judío a la tradición asimismo se dio en la querencia por el nombre de persona originario, siempre que no evidenciara su estirpe hebrea. Se ha comprobado en el caso de Joana Trigo y se aprecia en "Leonardo de Elí de Çaragoça,

de hebraístas e hispanistas, para explicar también los numerosos casos de formas con $c$ y $s$, el valor de la $h$ de Nahamen Atortox y de Mira Mehe del legajo de Antón Francés (77v, 88v), de un dominio que desconoció la velar /h/, las mismas variantes Judá-Hudá, Cinfa, nombre de judía de Magallón, y Cinha de otra de Calatayud, así como los también aragoneses GentóYentó-Entó y Jucé-Yucé-Iussé; o, del mismo legajo, el apellido Jucé Majo, variante Macho, pues Corominas en la entrada majo piensa si este adjetivo podría relacionarse con el judeoespañol maho 'tranquilo', transcrito majo en Nehama, ampliamente extendido entre los sefarditas de Oriente $(D E C H)$ : sobre textos romances en aljamía véanse Minervini (1992) y Lleal (1995). Es imprescindible, en todo caso, tener en cuenta la realidad lingüística del castellano y de los territorios castellanizados y bilingües, y la razón, lingüística o de tradición escrituraria, para la representación gráfica de nombres hebreos por parte de escribanos públicos desconocedores de esta lengua. En relación con esta alternancia onomástica, posiblemente se deba mencionar formas que en cuadernos de peajes del reino de Aragón de mediados del siglo XV encuentro, como chotas-jotas, ovejas, ovexas-ovechas, toronjas-toronchas (1993: 439).

19 Del Índice alfabético de los bautizados en la parroquia de Magallón, que comprende los que se hallan escritos en los siete primeros tomos de bautizados en dicha yglesia, desde el año 1549 hasta el 1786, hecho por don Lucas Velilla, vicario, el año 1797 (Archivo parroquial de Magallón). Además de los nombres de familia Francés y Gascón, con correspondencia en los documentos de la expulsión, se registran los antropónimos Antonio Gallego, María Royo, Gerónima Royo, siete apellidos Franco, y numerosos Pérez, una María Alias y un Josef Elías, esto en el primer tomo, el más próximo a la expulsión, nombres de familia que también llevaron miembros de esta comunidad hebrea, entre ellos Salomón Alias o "el jodío Alias". 
se llamó Simuel Elí quando judío", lo que no evitó que el converso fuera quemado un año antes de la expulsión, e igual comportamiento onomástico se descubre entre Ahin Francho (Franco), judío de Illueca, que, estando en Tortosa para ir "allende la mar", el 16 de agosto del año de la expulsión hace donación a su hermano Jaime Franch, ya converso, de las deudas que con él tenían vecinos de esa localidad y de otras comarcanas (Secall Güell 1982: 106), y explícito a este respecto es el testimonio del Rabí Bienvenís Arruetí, de la aljama de Daroca, dado el 15 de agosto de 1488 en proceso inquisitorial: "tenía mucha notiçia y conoçencia con hunos llamados Alonso de Santa Cruz y dona Blanqua (Blanca), y no se quiso mudar el nombre al fazerse cristiana, segunt a este deposant ella misma le dixo". (López Asensio 2016: 526)

2.3. A la cuestión idiomática afectaría que las juderías hubiesen sido estancas o poco abiertas a otras, o que, por el contrario, hubiera habido bastante movilidad de algunos de sus miembros en amplitud geográfica, lo que afectaría al trato entre religiones, incluida la mediación del importante sector converso, y al contacto con la variedad lingüística peninsular. Soy de la opinión de Alberto Várvaro de que el retraimiento de las juderías no fue tanto como a veces se ha supuesto, pues "tutto fa pensare que la mobilittà geografica degli israeliti fosse molto rilevante" $(1987: 158-159)^{20}$, y creo que el conocimiento de sus movimientos entre regiones arrojará luz sobre la complejidad dialectal del judeoespañol.

En la documentación referente a una judería importante como la de Calatayud se encuentran datos de viajes de varios de sus integrantes por diversos puntos peninsulares y de la presencia en esta ciudad de judíos de lejanas procedencias, no solo de aquellos dedicados al comercio: Burgalés, Castellano, de Segovia, de Castilla, de Murcia, el Mallorquí, de Palencia, Palenzuela, etc. Caso sobresaliente es el aportado por la declaración de Jacó Enrodrich en proceso de 1488 (López Asensio 2016: 390):

dize que viniendo una judía que se dizía la Portugalesa en esta ciudad de Calatayut, la qual era parienta deste deposant, era muy pobre y esta

20 El distinguido maestro italiano pensó en la constitución, o en el reforzamiento, de las aljamas del norte con migraciones desde el sur andalusí y en relaciones profesionales y familiares de gran amplitud geográfica entre los hebreos, concluyendo que "tutto ciò non puo restare senza conseguenze sul piano linguistico". La cuestión, sin embargo, es determinar, siquiera mínimamente, en qué habrían consistido tales consecuencias, quizá al menos en una cierta familiaridad de los judíos de una región con las peculiaridades dialectales de otras. 
dicha portugalesa tenía ciertos parientes en esta dicha ciudat, como eran la muger de Sperandeu Ram, que era hermana de la dicha portugalesa, y Johan López de Mayor..., de los quales parientes y de sus casas era socorrida y ayudada para todas sus necessidades.

No sería hecho migratorio aislado, pues hacia 1476 se atestigua un Simuel Parenti, de Portugal, en la judería de Huesca, donde también vivían los Arrondi, oriundos de esta nación, cuyos padre y hermano, maestros Mossé y Açach, se dedicaban a la medicina, y de un varón de esta judería, Joná Leví, se decía que había estado en Almería, aún del reino granadino (Marín Padilla 1982: 63, 70, 76) ${ }^{21}$. A menor escala la judería de Magallón asimismo ofrece muestras de actividad viajera, con las andanzas del Rabí Manuel ben Aljoar, en los textos de expulsión solo nombrado Rabí Manuel, requerido en tantos lugares por su saber astrológico, o del rico mercader Salomón Atortox, cuyos negocios llegaban hasta Albarracín y Valencia, con los sobresalientes casos de Açach Magallón, además de un hijo de su mismo nombre, Mayr Magallón y Semuel Magallón propietarios de casas en Huesca por 1475 (Benedicto Gracia 2003: 233-234). Figura Açach de León como testigo en una liquidación de bienes (73r $)^{22}$, y su apellido demostrativo es de origen occidental, nada extraño si en los nombres familiares de la villa se contaban varios Ubiedo y un Oviedo (v. n. 19); un Joan Gallego se halla como testigo de la venta del baño de los judíos junto al hebreo Jucé Francés (Texto III).

\section{LA JUDERÍA DE MAGALLÓN A LAS PUERTAS DE LA EXPULSIÓN}

\subsection{EL PROCESO DE DISOLUCIÓN ECONÓMICA}

3.1.1. No era populoso el barrio judío de esta villa aragonesa, pero tampoco de la población de hasta 130 individuos que se le ha atribuido. La cincuentena

21 Ya sabemos del sabio rabino siciliano oficiante en la judería zaragozana, donde también hubo uno llamado Faro de Granada (Tilander 1958: 16).

22 Por entonces era rabino en Ocaña $R$. Ishac de León, "uno de los últimos grandes rabinos de España" (Baer, 1981:560). Si en la judería de Magallón había un Açach de León, el apellido Zamorano figura entre los primeros registrados por bautismo de esta villa (v. n. 19), y un Abraham de León habitaba la judería de Zaragoza en 1405 (Blasco Martínez 1991: 78-79). 
de varones adultos documentados, más algunos otros que no incluyen los documentos de la expulsión, así como la alta natalidad propia de las comunidades hebreas, permite considerarlo integrado al menos por unos cien individuos más ${ }^{23}$. Contaba con sinagoga, en estos diplomas notariales su única forma es sinoga, y eran sus autoridades dos adelantados, un clavario 'custodio de las llaves', dos oficiales, uno de ellos de la plega (aragonesismo) o encargado de la colecta, y un corredor de la aljama para llamar a reunión con crida 'pregón'. Tenía, pues, esta aljama plena autonomía local y, como Baer afirma, "ninguna otra población judía de toda la ancha Diáspora acogió las ideas y tendencias políticas de su tiempo de forma tan clara como las aljamas aragonesas" (Baer 1981: 174). En cuestiones de interés común o aljamal, adjetivo usual en estos textos, no debían faltar estos prohombres, así en la liquidación de la sinagoga que se hizo casi in extremis, el 11 de julio:

Eadem die, que clamada e ajustada la aljama de jodíos de la dita villa por crida de Joan Gallego, cor[r]edor, en la sinoga de la dita aljama, presentes Yentó Çamel, Jacó Çaruch, adelantados, Mossé Atortox, clavario, Abram Vempesat, Abram Oficial de la plega, Jucé Majo, Açach Gallat, Abram Oficial, sastre, Açach Vedengar, Yentó Farag, Abram Moych e Yentó Gito..., vendieron a don Miguel Coll, scudero de la dita villa, las sinogas comunes de la dita aljama, que afruentan con casas del dito Miguel Coll e car[r]eras públicas e casas de Martín Sarassa, por precio de syscientos e cinquanta sueldos jaqueses. (Texto I) ${ }^{24}$

23 Al menos Açach de Leví, don Simuel Gotina y Salomón Azamel no están en la lista de 1492 de Motis Dolader, pero se hallan en textos desde primeros de enero al 30 de abril (6r, 14v, 36r), y el mismo hijo del R. Manuel al que luego me referiré. Escrito este artículo, aparecen en el Archivo Diocesano de Zaragoza dos documentos en hebreo que traduce Álvaro López Asensio, uno de los cuales se refiere al contrato crediticio entre los judíos de Tauste Haym Abenforna y Lezar Abenforna, inserto en proceso canónico de 1493 promovido por el primero con el nombre de Jayme García, maestro en medicina, bautizado para evitar su expulsión, contra Pedro López, vecino de la misma villa e hijo del segundo contratante, Luys López, también converso: El Periódico de Aragón, 22.08.2018, p. 37. No parece vana, pues, la sospecha que luego se esboza de amaños entre judíos y conversos en ventas y procuraciones como las que precisamente se acuerdan en Magallón con judíos del mismo Tauste, además con presumibles lazos familiares (cfr. 3.3.2.).

${ }_{24}$ Fs. 87v-88r. Comienza el documento en los últimos cuatro renglones de $87 \mathrm{v}$, y como testigos figuran Simón Gallipienço y Salomón Atortox, mercader y la persona más rica de la judería, elegido para tan crucial venta. Este nombre puede también leerse Salamón y Solomón; transcribo sueldos de solos con signo de abreviatura de solidos, proveniente de la anterior escrituración en latín. 
Es el esquema que, con mayor o menos intervención de varones ajenos a la dirección de la aljama, se repite en semejantes circunstancias notariales, ventas aljamales como la precedente y las del hospital y baño judíos, de las casas de la judería a que obligaba el pago de una deuda común, y la redención de préstamo sobre la "peyta e sisas". La satisfacción de los debidos impuestos reales se haría el 5 de julio en Zaragoza ante el lugarteniente del baile, por medio de los comisarios de la expulsión Pero Navarro y Joan Francés, juez de la Hermandad $(81 \mathrm{v})$.

La liquidación de bienes particulares y comunes se cumpliría en exiguo y asfixiante plazo, entre el 2 de mayo y el 17 de julio, como en las demás juderías aragonesas. El 30 de abril, presente el notario "e toda la aljama de jodíos", esta institución se compromete a pagar al escudero Miguel Coll "cinquo mil y cincientos sueldos jaqueses" que le debía, y a tal efecto se nombraron peritadores, dos cristianos y dos judíos (42v); el siguiente paso lo da dos días después el rico Salomón Atortox en su propia casa, declarando haber recibido parte de lo que le debía un cristiano de Borja (43v). Precisamente en su vivienda este mercader el mismo 2 de mayo, "ante la presencia de don Francisco Cabanyas, habitant en Çaragoça, comisario de la santa Inquisición", en compañía del notario Antón Francés y de las autoridades de la villa nombradas para vigilar los trámites de la expulsión, compareció dicho don Salomón, manifestando que "quanto a la inventariación facedera por part de los señores inquisidores, que louaua (sic: loava) e aceptaua e le placía se ficiesse en buena hora":

Enpero que quanto al interesse de los deudores e crehedores de la dita aljama facedera, que no consintía ni le placía, ante protestava e protestó, e que salbo le quede su dreyto por lo esdevenido ante. Que él aljamalment ni singular no deve cossa alguna, atento que él, quanto a los deudos aljamales, él tenía tal pacto convenido con la dita aljama e oficiales della, del qual en judayquo fiço fe, allí presentes Jucé Majo, Jucé Oficial Çaruch, Yentó Açamel e Abram Oficial, sastre, Mossé Atortox, Jaccó Çaruch, oficial de la dita aljama, e otros jodíos de aquella que publicament confesaron e reconocieron que era assí la verdat e tal passava entre ellos por aquel acto judayquo. De las quales cossas el dito Salomón requirió por mí de acto público. (Texto II) $)^{25}$

25 Fs. 43v-44r. Nótense el modal aragonés “aljamalment ni singular" y el verbo esdevenir. Excepcionalmente, en este acto figuran dos testigos cristianos, Pero Francés mayor y Joan de Arnedo, y uno judío, Simuel Arruetí; en los demás solo son dos, uno de cada religión, tres si también consta un musulmán en el trato. 
3.1.2. Sorprende que los judíos de Magallón, pero algo parecido ocurrió en otras juderías, no comprendieran el terrible peligro que los acechaba, ni un mes después de promulgado el Edicto de Santa Fe, pues en el mismo abril aún estaban haciendo compras y préstamos a cristianos y moros. Incluso se dio a primeros de febrero un trato de Salomón Atortox por los "quatro anyos primeros vinientes" $(15 \mathrm{v})$, cuando negros nubarrones amenazaban con la tormenta que no tardaría en descargar, y el 16 de enero todavía contrataría obras este mercader con el maestre Lope Tapiador (8r-9r). Hasta pasados varios días desde que se habían puesto en marcha los trámites de la expulsión no se advierte la reacción de la comunidad hebrea, incrédula tal vez ante la situación dramática a que se veía abocada, pues será el 16 de mayo cuando Jaccó Çaruch promueve en acto notarial el perdón a María Vicent de cuanto le debía (45v), siguiendo luego ventas y condonaciones de varios miembros de la judería.

La aljama paga puntualmente sus deudas comunales, no se registran de particulares judíos, pues la de cinco mil quinientos sueldos "de propriedat" y doscientos setenta "de pensión"contraída con Miguel Coll, ya las satisface el 30 de mayo mediante la entrega de casas, y los impuestos debidos al rey se abonarían el 5 de julio. Los más preciados bienes aljamales se enajenan escalonadamente: "hun spital de la aljama que afruenta con las sinogas e car[r]eras públicas" (52v-53r), el 30 de mayo; el baño de los judíos el 13 de junio, y finalmente las sinagogas, tal vez la de hombres con el estrado de las mujeres, el 11 de julio (Textos I, III). Mientras, se sucedían las ventas individuales y numerosas condonaciones de débitos, con lentitud que parecía se esperara un milagro que no llegó, y al final, desde mediados de junio, se aceleran las "vendiciones", incluso con subastas, las dos que el 8 de julio se hicieron con propiedades de Aym Amillo (82v-83r), así como los nombramientos de procurador para el cobro de deudas, en el caso de Salomón Atortox a un notario de Mallén para que cancelara la que con él tenían varios habitantes de Valencia, en el perentorio 17 de julio.

\subsection{LA CUESTIÓN SOCIAL}

3.2.1. No hay en esta documentación indicio alguno de conflictos o malquerencias entre cristianos y judíos, pues todo se desarrolla en los discretos términos de la contratación notarial, y se ha visto cómo ante el comisario de la Inquisición y autoridades locales el mercader Salomón Atortox enérgicamente protestaba en defensa de sus derechos, reglados según "aquel acto judayquo" de la aljama, y cómo a los judíos presentes se les permitía confirmar su declaración en ritual e idioma hebraicos (Texto 
II). Este mismo personaje continuamente tiene el tratamiento de don, que se daba a los judíos de edad y relevancia social y económica, y el pelaire Joan Alonso lo menciona como "vos, don Salomón Atortox" un 27 de enero de 1492 (14v), y un don Simuel Gotina aparece en el mismo folio y día, en acuerdo de comanda. Pero también recibe este título el musulmán rico y destacado en su comunidad, como era el caso de "don Gimeli, moro de Albeta", en acto notarial del 5 de abril con los testigos "Pasqual Cellón de Magallón e Mahoma Gimeli, moro de Albeta"26.

En cuanto a la convivencia entre religiones, buena idea da la misma liquidación de los bienes de judíos, cuyo primer acto consiste en el perdón de deuda de Jaccó Çaruch a una mujer de Alberite, hasta el punto de que, en los documentos posteriores al 30 de abril, las actas levantadas entre el 16 de mayo y el 17 de julio en al menos una veintena son de condonaciones de deudas a cristianos de Magallón y de otras localidades, así como a favor de moros de Agón y de Bureta ${ }^{27}$. En las ventas no hay distingos de religión, pues Abram Abempesat y Abram Leví enajenan propiedades a la "lámpada de la lumbraria de sant Sevastián" (68v), habiendo sido "mossén Miguel Francés, clérigo" quien compró el baño de los judíos. El mismo R. Manuel el 17 de julio concede a Miguel de Ribera los derechos sobre sus heredades $(90 \mathrm{v})$, y en los contratos anteriores al Edicto diez van cancelados, varios con anotación notarial al margen.

3.2.2. La clase social la determinaba el poder económico, ejemplo de ello es el mercader Salomón Atortox, y la jefatura espiritual del rabino, que al menos le proporcionaba prestigio a él y a su familia. No en vano, la mujer del R. Manuel no solo protagoniza, como otras judías de su comunidad, la liquidación de las propiedades de que era titular, y junto a su marido en las de dominio matrimonial, sino que excepcionalmente se halla presente en la venta del baño de los judíos junto a los dirigentes de la judería:

26 El tratamiento de respeto se da en el cuerpo del texto notarial, nunca al pie de la relación de testigos. El 13 de mayo de 1342, Gil Garro, "notario público de Magallón”, valida la concesión de esta villa, y de Alberite, Bureta y Albeta, a Pero Blasco, vecino de Borja, para el cuidado del azud y acequia de Marbadón (Pergamino del Archivo Municipal de Magallón), donde figuran don Mahoma d'Apnahar, vasallo de "donna María Garçía de Albeta", y "don Avy d'Almoraf, moro, vassallo de dito Pero Xeménez".

27 Otorgan estos libramientos de deudas Salomón Atortox, en muy destacado lugar, Mosé Atortox, Rabí Manuel, Yentó Farag, Yentó Gito, Jucé Belmoder y Abram Oficial. 
Eadem die, que Rabí Manuel e Solí, su muller, e Simuel Velmoder e Jacó Çaruch e Yentó Açamel, adelantados de la aljama, en nombres propios e como adelantados... vendieron a mossén Miguel Francés, clérigo de la dita villa, dos guertos con el Banyo clamado de los jodíos de la dita villa... por precio de trecientos sueldos jaqueses. (Texto III) ${ }^{28}$

Las tensiones en este recinto hebreo sin embargo no habían faltado, como en tantos otros en los que la controversia religiosa, la desigualdad económica o el mal gobierno provocaron rencillas y aun violencia, como la que estalló el año 1385 en la aljama de Zaragoza (Baer 1981: 355). Así, el 21 de octubre de 1483 el baile responsable de la judería de Magallón llamaba a 22 de sus miembros a una reunión en Casetas, lugar vecino de Zaragoza, donde, promete, "vos aclareçeré vuestras differencyas e porné reposso en aquessa algama", porque "destos días por algunas differencyas que ay entre voshotros e quexas que a mí an dado algunos d'aquessa alguama, así por aver saquado los adelantados que saquaron, como aun en aver las ordinaciones fechas". (Motis Dolader 1984: 146-147)

Pero al parecer se trataba de conflictos limitados al grupo judaico, independientes de los que afectaban a la comunidad cristiana, como los que esta vivió en vísperas de 1492, a tenor de la providencia dirigida al justicia de Magallón el 2 de enero por don Alonso de Aragón, arzobispo de Zaragoza y lugarteniente general del reino, ordenando la suspensión de los oficios de la villa: "por quanto nos tenemos relación que, a causa de las passiones y tirana governación y mal regimiento dessa dicha villa, la cosa pública de aquella recibe grant detrimento..., suspendemos y por suspendidos haver queremos todos los officios dessa dicha villa, excepto a vos"29.

28 Fs. 61r. Venta acordada el 13 de junio por precio irrisorio, como lo fue el de 650 sueldos por la sinagoga, el más preciado bien de la aljama, retenido por la comunidad judía hasta el 11 de julio, cuando ya expiraba el plazo para la enajenación. Conocida la ubicación de esta judería, no sería difícil localizar el sitio del Baño de los Judíos y de los huertos aljamales con él vendidos, "que afruentan con guerto de Pero Pueyo e con cequias e con guerto de Joan de Prat". En los testigos del acta anterior Velmoder es Abelmoder.

29 Dada en Zaragoza el 2 de enero de 1492, con firma autógrafa de don Alonso de Aragón, como la lleva la que expide el 14 del mismo mes con el nombramiento de Joan Francés como "official mayor de la Hermandat en la dicha villa"; este personaje y el justicia Pero Navarro serían los encargados de supervisar los trámites conducentes a la expulsión. Los dos pergaminos están insertos entre las hojas de papel verjurado del legajo estudiado (caja 181 del Archivo Municipal de Magallón). 


\subsection{ENTRE EL DESTIERRO Y LA PERMANENCIA}

3.3.1. Llega la expulsión no sin que deba resolverse un litigio de última hora, el que enfrentó a Martín de Gurrea, comisario regio para la conducción de los judios fuera del reino, con Pedro Navarro y Juhán Francés, comisionados "para conocer de los deudos y cargos que los judíos desta villa tenían", quienes pretendían ser los conductores de la grey hebrea, lo que obliga al escudero Álvaro Homedes, representante local de dicho comisario, a intimar a los oficiales de Magallón el 17 de julio:

Comparece Álbaro Homedes, escudero abitant en Magallón, assí como procurador del magnífico Martín de Gur[r]ea, senyor del lugar de Argauieso, comisario ques por la magestat del Rey nuestro Señor para guiar y sacar todos los judíos y judías, assí grandes como pequenyos, del regno de Aragón, segunt que de su comisión más largamente consta... Por tanto suplica y requiere a vosotros dichos juges que no guiéys los dichos judíos ni les deys guiaje ninguno como aquellos, y el guiar de aquellos sea remeso a su real magestat o al dicho mi principal. En otra manera, si el contrario fazéys, lo que se crehe, protiesto contra vosotros. $(\text { Texto IV) })^{30}$

Seguramente el nutrido grupo de exiliados tuvo un primer recorrido corto, pues si muchos judíos aragoneses fueron llevados al vecino reino de Navarra, razón de más es que ese camino siguieran los de Magallón a la villa fronteriza de Cortes, distante unos 11 kilómetros, e indicio puede ser de ello que Abram Oficial admitiera como pago de unas casas una pieza de paño, una copa de plata de ocho onzas y un asno negro, a finales de junio (70v). Más adelante se les facilitaría a los acantonados en la Ribera navarra medios para llegar por el Ebro a Tortosa, donde embarcarse, lo que unos harían y seguro es que otros pasaron a Francia. Junto a los demás contingentes peninsulares serían los que por recuerdos, rasgos culturales y lengua se llamarían sefarditas, que en Salónica a finales del siglo XIX proclamaban “iViva el judeo-español!”, “iPor la lengua madre!”(Romero

30 F. 91bis. De la tradición textual aragonesa tiene juge 'juez', catalanismo que en aragonés convivió con judge, común en las dos manos del testamento de Coloma, y con júdez, juyz (Tilander1956: 167-168). De señalar es el participio fuerte remeso, frecuente en el aragonés y castellano de este dominio en la época, y la variante innovadora deudos; también es sistemática en el texto la pérdida de la /-d-/ en avéys, deys, etc., constante el pronombre compuesto vosotros, y corriente era aún su doble negación ninguno no pueda, además de la diptongación protiesto. 
1969: 199), igual que a principios del XVIII en el hermoso y emocionante texto de un rabino de origen hispano, entrañable muestra de lo que fue la aventura sefardita en América, se produciría semejante exclamación de amor hispano. Precisamente con esta voz se apellidaba Mosé Sefardí de Huesca, bautizado como Pedro Alfonso con el padrinazgo de Alfonso el Batallador el 29 de abril de 1106, diez años después de la reconquista de esta ciudad, personaje políglota, famoso por su Disciplina clericalis, así como por sus saberes astronómicos y médicos. (Millás Vallicrosa 1943)

3.3.2. Alguna exoneración de deuda al final de la actuación notarial levanta la sospecha de que amañaba la salvaguarda de peculio para un posterior regreso, y sobre todo ciertas procuraciones para cobro de débitos y enajenación de bienes urbanos y rústicos, al menos seis se hicieron, cuando a todas luces ya no era posible su cumplimiento, en particular la de Salomón Atortox a favor de "Aym Atortox, fillo de Salamón Atortox, jodío de Taust" (77v), del 29 de junio, y la que Açach Çaruch y su mujer Mira Mehe encargan el 14 de julio a "Jucé Atortox, jodío de Taust, fillo de Nahamen Atortox"(88v). Pero más inquietante aún es la venta de todas sus propiedades que el 11 de este mes hace Alaçar Arruetí a su mujer Ezter Albo por 1.000 sueldos (84v), lo que permite pensar que ella iba a ser conversa. Parecidas dudas suscitan las liquidaciones hechas por judíos de Calatayud, casi todas ejecutadas desde el 10 de junio, hasta el 19 de julio, cuando se cierra la de un rezagado, si bien el sastre Jucé Azarías, probablemente presintiendo el peligro, el 2 de febrero comienza la venta de sus bienes, que remataría el 28 de mayo, y curioso es que Mosé Constantin entregara a Regina Alazar, hija de Simuel Alazar, 2.500 sueldos en ayuda de matrimonio, justamente el 17 de julio (Borrás Gualis 1969: 47). En este sentido histórico va la intimación notarial que el 28 de mayo de 1492 se hizo en la sinagoga mayor de Zaragoza para que:

dentro de ocho días de oy adelant fuessen e sean tenidos revelar e notificar bien, fielment e verdaderament qualesquiere bienes que ellos tenían o havían ocultado, assí teniéndolos en alguna part scondidos, como haviéndolos encomendado a personas de qualesquiere ley, estado o condición sean, como en qualesquiere otra manera haviéndolos alienado o malmetido. (Cabezudo Astrain 1955: 114)

El episodio quijotesco del morisco Ricote (II, 54) fue real en muchas ocasiones, y esos medios de ocultación de bienes contra los que en la aljama zaragozana se advierte, tal vez tuvieron alguna práctica en la de Magallón. Desde luego casos de regresados del destierro se conocen, como el del converso cordonero Juan Atoleto, que, siendo judío, en la expulsión fue a Turquía, de donde volvió y vivió en Zaragoza, protestando que "nunqua 
mejores días hove que quando era judío y levava basura en Turquía" y "que deseava volver ayende" (Marín Padilla 1982: 286) ${ }^{31}$. No sabemos qué suerte correría Ezter Albo, pero no parece que acompañara a su marido al destierro, y en la lista de la liquidación no figuran varios judíos atestiguados en los primeros cuatro meses de 1492, uno de ellos Mayl Manuel, hijo del rabino, ni otros que, estando documentados pocos años antes, no se registran en los días previos a la expulsión, entre los cuales pudo haber conversiones, e indicios hay de la existencia de anteriores confesos (v. ns. 23, 31) ${ }^{32}$.

\section{ACERCAMIENTO AL JUDEOESPAÑOL PENINSULAR}

\subsection{LA PREEXISTENCIA DIALECTAL}

A la diáspora marcha una multitud de judíos españoles de la mayor diversidad regional y cultural, con el común nexo castellano, de exclusivo uso en buena parte de la Península, en distintos grados compartido en las zonas bilingües y por muchos portugueses conocido, aparte de que en su boca lo llevaban los que de Castilla se habían refugiado en el reino vecino. Los escritos notariales de nuestro legajo se redactan en el romance regnícola, pero el notario Antón Francés asimismo escribe en un castellano incluso más correcto que el aragonés de su protocolo, y las dos providencias dadas a la autoridad de Magallón por don Alonso de Aragón en buen castellano van, prueba de que esta lengua ya se hablaba en dicha localidad, cuya documentación desde 1511, tanto de asuntos privados como públicos, es castellana, mezclada de algunos rasgos dialectales. En los escritos rurales de la expulsión citados ya alternaban argent y plata, octobre con janero 'enero', un aislado ochenta frente a los dominantes numerales del aragonés, y sueltos dicho, dicha entre los corrientes dito, dita. Pero significativo es que en el nivel informal un moro se apode el Pájaro, o que apellidos y motes se sufijen -illo, no -iello, así la hebrea Aljonar del Portillo y el cristiano "Joan Bueno alias Bonillo" (40r).

31 Desde 1493 hasta 1505 diez expulsados de Calatayud volvieron a su tierra ya conversos o para convertirse (López Asensio 2016: 100).

32 Un Mair vivió en la judería de Zaragoza y Mayr Oficial se documenta el año 1484 en la de Magallón, como otro Mayr Magallón por entonces era propietario de predio urbano en la judería oscense (Benedicto Gracia 2003: 233). La /-1/ final de Mayl resulta de la ocasional neutralización de /-r, -1/, que, lejos de su intensidad meridional, se daba y se da en Aragón; de hecho, en este legajo está la forma fosar 'fosal' (41r). 
Aparte de lo que suponía la conservación del hebreo, aunque fuera en grupos minoritarios, no puede descartarse una situación de bilingüismo, o de diglosia más bien, seguramente con predominio del castellano, en el que también el baile de la aljama había citado a 22 de sus miembros a la reunión de Casetas del año 1483 (v. 3.2.2.), idioma en el que sin duda se mantuvo su conversación con el justicia zaragozano, y con el que tuvo que usar el R. Manuel en su trato con influyentes personajes, y en sus traducciones del hebreo al romance. De Salomón Atortox sabemos que pidió copia de un texto notarial, y, por testamento del rico ganadero Juan de Linares, del 14 de marzo de 1492, que llevaba al día por escrito el estado de sus negocios: "Y tem, lexo e mando que sía pagado a don Solomón Tortox, de la dita villa, todo aquello que él mostrará por su libro de lo mío, luego que yo finaré" (31r). El entorno rural de la judería considerada condicionaría una mayor pervivencia de dialectalismos y una menor corrección en su castellano que en el de personajes de las grandes aljamas, o que en el de Gonzalo García de Santa María y de un Felipe Climente, protonotario de Fernando el Católico, que en nada se diferencia del de Juan de Coloma, cristiano viejo de gran influencia en la Corte, cuyo dominio lingüístico es equiparable al de los más cultos de España, aunque con sus peculiaridades aragonesas, como los de otras regiones tenían las suyas.

\subsection{UN AVANCE DOCUMENTAL}

El interrogatorio de los procesos inquisitoriales es inagotable fuente de conocimientos culturales, folclóricos y lingüísticos, y así en su deposición María Díaz (Calatayud, enero de 1488) recuerda que, teniendo ella doce o catorce años, en casa del acusado se comían rosquetas y confites (553), que le enviaban pan cotazo o cenceño y que su señora le decía los sábados, “quando guisava berças, que tomasse del dicho pan çençenyo y que lo picasse con el queso y que lo echasse en las berças". No solo eso, sino que proporciona la receta de las albondiguillas, a las que tan aficionados son los sefarditas:

vio que la dicha su senyora guisava albondaquillos en esta manera: que capolava la carne y con salssas fazía de la dicha carne unos redolinos y freíalos en azeyte y comíanlos los dichos sus amos...; otras vezes tomava los dichos albondaquillos y metíalos dentro de unos alvillos de carnero y, atados con filo, echávalos a cozer en el caldo. (López Asensio 2016: 553) $3^{33}$

33 Para aligerar las menciones de este corpus, en adelante pondré bastantes citas suyas solo con la página entre paréntesis. 
Apunta Corominas que "los judíos sevillanos en Palestina seguían comiendo en 1512 las "albondeguillas et adafinas", como en España" (DECH), y a buen seguro los originarios de Aragón seguirían la misma costumbre allá donde se hallaran. Con la velar del ár. búnduqa, y en femenino, albondaquillas tabaheas o tabaeas $(427,431)$, y con /g/ albondiguillas (432). Se comían arrucaques 'torrijas' y alcahalillas, turrados el pan cotazo o cenceño y los garbanzos $(387,389)$, tortas de pan (549), y las rosquetas eran "fechas con specias y çafrán" (390). Dice la declarante que "la dicha su senyora le mandava, quando había de degollar este testimonio alguna ave, que covixasse la sangre de las dichas aves, y que esta deposant assí lo hazía, que la covillava con estiércol o con tierra" (553). Asimismo se atestigua leyura 'ley (religión)', con sufijo de gran rendimiento en judeoespañol, y retreta, "dentro de la dicha sala hay huna retreta siquiere estudio" $(249,395)$, y un lieudo que corresponde al levdo 'fermentado' de los judíos españoles, aunque con diptongación de la breve etimológica: "al tiempo de la pascua de los judíos levava a los judíos pan lieudo, lechugas, y a él davan alcahalillas y turrado y massa lieuda"; "él enviava a este testimonio pan lieudo y lechugas" $(405,521)$.

En las declaraciones testificales se encuentra el rasgo fonético resultante del bilingüismo hebreo-romance, así en la del judío Jucé Çarfatí, del 6 de octubre de 1488, sobre el acusado bilbilitano Simón de Santa Clara, que, "havrá vinte annos", se burlaba de los cristianos y decía: "avanti christiani, y ponti del duelu con to cuaresma", un judío oscense se llamaba Parenti (v. 2.3.), y otra vez "duelu les venga", y a un hijo suyo en día en que la carne estaba prohibida: "ven aquá, amatu; pues havemos comido, digamos la berahá" (515). Y en el mismo proceso el 17 de marzo Mossé Catorçe, judío de Illueca, afirma que "abrá XXX annos, poco más o menos", estando en Daroca "en día de Corpus Cristi vido este deposant cómo los cristianos fazían un entremés... y que yban unos diez cristianos como judíos cantando y dezían los unos esta canción: De las coles, con el culantru, oréganu" ${ }^{34}$.

El conocido apellido Constantín de la judería de Calatayud a veces se lee Gonstantín, como el de la conversa Constanza o Gonstanza, con alternancia $\mathrm{de} / \mathrm{k} / \mathrm{y} / \mathrm{g} /$ que a la inversa presentan los de Sallamón y "Azmel Churchullu, fillo de Salamón", y con la característica inflexión vocálica, en Zaragoza el año 1331 (Tilander 1958: 10), aquí ch es grafía de /k/, alteración del arag. gorgollo 'gorgojo', 'persona de pequeña estatura' en acepción figurada; 
habiendo existido en la misma judería el año 1426 un artesano sedero conocido con las variantes Imano-Emanu (Blasco Martínez 2006: 65). A retazos se documentan antes de la diáspora rasgos del habla judeoespañola, pero van apareciendo a medida que progresa la pesquisa documental, así en la referencia de Baer a la revuelta que en 1385 hubo en la aljama zaragozana por haber sido encarcelado el rabino, viéndose invadida la casa del causante a los gritos de “imuyre Salamón Abnarrabí, muyre!” (Baer 1981: 355), sin que el refranero desconociera este verbo con la misma inflexión vocálica sefardita: "Más vale murir judío, y no murir turco". No es, pues, murir creación extrapeninsular, ni probablemente su lexicalización; tampoco el sufijo -ites, en testimonio de Samuel de Medina de comienzos del XVI, "para esto venites aquí, para fazer sematah" (Marcus 1962: 136), puede darse por formado en el exilio, existiendo en hablas andaluzas, también en América -ates, -ites (o -ite), incluso con un fuite en los Cuadernos de Londres de Andrés Bello ${ }^{35}$.

A la conservación judeoespañola de la prepalatal fricativa sonora /3/, y correspondiente sorda del par fonemático, refiere el insulto que un acusado de judaizar dirigía a su nuera: “¡Calla, corneya ...!” (513), sobre el castellano corneja (y meyesa, de mege), así como, seguramente, las variantes JacóYacó, Jucé-Yucé, son numerosos los casos de Yucef y Yocef, y Gentó-Yentó, en la misma judería de Calatayud y sus tierras; siempre Jucé, nombre de siete varones, en las actas de Antón Francés, pero en ellas, salvo un aislado Gentó, continuamente aparece Yentó, con el doblete Jaccó y Yaccó (v. n. 17). A las sibilantes implicadas en el característico seseo sefardita conciernen la alternancia çofer-sofer 'notario judío de la aljama', un seseante texto castellano puesto en hebraico (López Asensio 2016: 236-237, 299), con otros ejmplos en 4.3., y el apellido Pazagón, corriente con ç, también se halla como Passagón, igual que $A$ çach, reiterado en los textos de Magallón, y en otras juderías, también puede verse escrito Asach. Asimismo el nombre de judía Clariça, la grafía Yzrael, y en la comparación que los conversos hacían entre Jezabel e Isabel la Católica, impulsora de la Inquisición, habiendo sido acusado uno de que dijo: "esta nuestra Reyna es aquella que también se llama Ysabel, que quiere quasi dezir Yzebel" $(231-232,408)$. En el legajo del notario Antón Francés serán los nombres de la judía Ezter Albo, y del moro Yça Ezmael, con $-z$ donde el romance tiene $-s$, como Nebrija c.1495

35 A principios del XIX literariamente se contraponen los dexates, venites, pusites del personaje popular al visitaste, volviste del culto (Frago 2012: 75, 83). Y cfr. n. 41. 
anotó: "Izmael, nombre de moro, Hismael" (c. 1495/1989: s.v.), así también en la Biblia ferrarense y en muchos testimonios inquisitoriales.

\section{3. "Royo”, DEL ARAGONÉS A LAS JUDERÍAS DE LA DIÁSPORA}

La vivencia rural o urbana, la clase social y el ser letrado o iletrado marcaron al hablante medieval, más profundamente aún a los habitantes de las juderías en lo que al dominio del romance se refiere, de manera que sin duda fue en el elemento popular donde se fraguaron los rasgos que más darían carácter al judeoespañol. Ese medio social dio aliento al refrán, trascendido al castellano, Costumbre es de judio en comiendo tener frío, con equivalente El aragonés fino en comer tiene frío, coincidencia que con claro tinte dialectal se muestra en el empleo y matiz social de royo entre aragoneses y judeoespañoles, teniendo en cuenta que este adjetivo, aunque referido al pelo puede ser 'rubio, de color parecido al del oro', como el diccionario académico indica, más propiamente significa 'pelirrojo', por tanto el individuo raro, como el zurdo, por los demás visto con recelo. Muy clara tenía esta cuestión diatópica y semántica Correas (1627/1967: 456) en su comentario al refrán Párate, rroia, ke xurado soi del Almunia ("En Aragón rroia es mula rroxa"). Esta voz fue apellido y apodo frecuente entre conversos, así "Salvador de Santángel alias el Royo", Spes el Royo, Miguel Martínez el Royo "confeso por la madre, que es de los Maluendas de Calatayud" ( $L V A, 44,70,75)$; en el legajo de la expulsión de Magallón se encuentra Nicolás Royo (59r), y varias veces en las primeras actas bautismales de esta villa. Su aragonesismo en judeoespañol es incuestionable y de arraigo en las dos culturas la malquerencia que al pelirrojo se tenía, evidente en el dicterio sefardí Royo, mal pelo, kavesa de kodredo (Nehama 1977: 485), siendo también en dicha localidad aún corriente la expresión royo, mal pelo, con adiciones despectivas.

No falta en los procesos inquisitoriales la mención al royo, así en uno que corría en 1488, con testigo que declara contra un hebreo convertido y ordenado sacerdote, que se burlaba del sufrimiento de Cristo en la cruz: "don Rabí judío, que se havía tornado cristiano y era un hombre royo que preycaba..."; pero la culminación maligna de este término se da cuando en 1509 un vecino de Bubierca, cristiano nuevo, de él se servía en capital blasfemia: "pesar de Dios y de la puta su madre y del royu de su hijo" (273-274, 277).

Sí parece, pues, que donde se mantuvo algún uso del hebreo hasta la expulsión el romance de los judíos se viera afectado por tal circunstancia lingüística, pero la cuestión es documentarlo con alguna concreción. En una judería rural como la de Magallón los varones juran en hebreo, por 
más que pudiera ser en expresión formularia, y se regían comunalmente por aquel acto judayco, al tiempo que piden copia del texto notarial, y en dicha comunidad la tradición hebrea debía persistir, pues es seguro que su rabino podía manejarse en la lengua patrimonial, no solo en el contexto bíblico. Hasta el punto de que el hebraísmo cal 'sinagoga y conjunto de sus fieles', de donde 'barrio de judíos', que no usaron los notarios aragoneses, pero sí los escribanos judíos en los documentos propios de la aljama, muy probablemente se halla en la base de Calentejo, nombre aún actual de la calle que fue la central de esta judería, desde su entrada hasta la Plaza del Castillo, muchas de cuyas casas eran judías. De hecho, aunque se da cal como término ajeno a Aragón, habría sido propio del dominio catalán (call), indicios hay de que traspasó los límites escriturarios del notariado judío, pues varios miembros de la aljama de Calatayud acuden a un escribano público cristiano para que requiera al "çoffer de la aljama... que él como çoffer del cahal de la dita aljama...", hebraísmo sofer igual que çidur 'sidur' (556), y en 1435 un converso vende unas casas en la judería confrontantes con "el cal del varranco", el barrio del Barranco era el de la judería, además de que en texto latino de 1388 se documenta "callem seu judariam" referente a Calatayud, además de que cahal con artículo árabe fue apellido de un zaragozano Haim Alcahal, a principios del XV (Blasco Martínez 2006: 76) ${ }^{36}$. Tal vez valga la pena citar en este punto el sefardí kaleziko 'petite chapelle du culte juif, oratoire' (Nehama 1977: 262), por lo que tiene de vulgarización del hebraísmo cal y de su apariencia aragonesista; de hecho, en Salónica ha existido el Cal de Aragón, que agrupaba sefarditas de esta procedencia.

\section{TRADICIÓN Y FACTOR SOCIOLINGÜÍSTICO}

\subsection{EN EL TRANCE DE LA CONFIGURACIÓN DE LAS HABLAS SEFARDITAS}

Los judíos expulsados, aparte de los que pasaron a Francia, Italia o Paises Bajos, se desparramaron por el norte de África, Grecia, regiones balcánicas y Mediterráneo oriental hasta Turquía, con un fondo lingüístico común, pero también con sus diferencias de orden dialectal y sociocultural. Cantera da una visión sucinta y plausible de la formación del judeoespañol, convertido 
en lengua comercial de este amplio marco, según lo advertido en 1606 por Gonzalo de Illescas, quien afirma haber conocido "en Venecia hartos judíos de Salónica que hablaban castellano, con ser bien mozos, tan bien o mejor que yo", pero con la aguda observación de Bernardo de Aldrete de 1614 sobre el hecho diferencial por el arcaísmo del "lenguaje que llevaron della (España) i se reconoce que es de aquella edad, diferente del desta", un idioma transmitido generación tras generación "por boca de madre" 37 .

La transmisión materna oral, sin enseñanza reglada, robustece la tradición idiomática, el anclaje en el arcaísmo y la variación formal. El judeoespañol en su etapa peninsular tuvo mujeres que en buen número se manejaban en romance, pues ya en 1372 el rabino de la aljama de Zaragoza desaprobaba la costumbre de leerles el libro de Ester traducido, recuérdese el caso de la cristiana nueva de Ayerbe a la que el Rabí Manuel de Magallón "saquava libros en christianego" y vertía "del Salterio la flor de los salmos y oraciones" (Baer 1981:353), y ese papel transmisor también hizo que algunas conversas procuraran enseñar a sus hijos la lengua sagrada, de acuerdo al refrán hebreo que corría entre confesas de Calatayud, Judios me da fijos, yo les faré aprender ebrayco ${ }^{38}$.

El conservadurismo anterior a 1492 se hará mayor en el exilio por el reclamo identitario del judeoespañol y su inclusión en escenarios de otras culturas y lenguas, sin suficiente contraste inmediato con los pasos que el castellano estaba dando en su evolución. En las nuevas comunidades sefarditas se producirá una nivelación principalmente inclusiva de no pocas variedades dialectales que a ellas afluyeron, con alguna semejanza a la verificada en el español de Andalucía, de Canarias y de América, aunque sin su misma generalización y fuerza innovadora, pues, por ejemplo, los mismos cierres vocálicos mencionados se asentaron en zonas periféricas de la diáspora, mientras que en las centrales las realizaciones abiertas de /e/ y /o/ prevalecieron (Hassán 1988: 130). Entre los sefarditas la innovación fue importante en el léxico, acompañada de bastantes modificaciones fonéticas, con la admisión de voces del nuevo entorno lingüístico, turco, árabe, griego

37 Palabras de Henri Besso que coronan el Preface de Jesús Cantera al Dictionnaire de Joseph Nehama (VII-XI).

38 El adagio lo pronuncia una cristiana nueva después de la alabanza que su marido hace de un converso castellano: "qué agudo este hombre y qué sabido con el ebrayco que sabía y después con lo cristianego que ha aprendido" (López Asensio 2016: 234). Sin duda había muchas más mujeres desconocedoras del hebreo que hombres, y significativa es la onomástica femenina, de nombres como Blanca, Bella, Bona, Camila, Cidilla, Clara, Clarisa, Del Portillo, Estrella, Fermosa, Leoneta, Lumbre, Luna, Oro, Orosol, Orovida, Preciosa, Regina, Reina, Sol, Sol Bellida, Solita. 
o eslavo, además del continuo aporte del hebreo, sumados los numerosos préstamos italianos y franceses; de hecho, el sefardí es innovador en todo lo que se ha desviado y añadido "respecto a sus orígenes castellanos" (Hassán y Romeu: 1992: 169). Pero siempre presente está en el judeoespañol el poso tradicional, muy marcado en la mujer, razón de que sus usuarios lo llamen "la lengua madre", lo que asegura que antes de la expulsión muchas hebreas dominaban el romance, presumiblemente en su variante popular $\mathrm{y}$, según lo que la posterior historia sugiere, con bastantes incorrecciones. Como Sala advierte, la conservación de /f-/ se tiene "en algunas regiones como un rasgo característico del habla de las mujeres" (Sala 1996: 363). Y de hecho, Nehama en todos los dobletes del tipo fambre-ambre, farto-arto, ferida-erida califica de "forma noble" a la que no tiene $f$.

\subsection{Judeoespañol y CASTELlanO DEL SIGLO XV}

5.2.1. A finales del cuatrocientos, la vocalización o pérdida de la /-b/ etimológica primaria ( $c i b d a d$, debda) o secundaria (cabdal) estaba avanzada, pero sin homogeneidad diatópica, pues el mismo Valdés mantenía el uso antiguo, mientras en amplias zonas norteñas el cambio había triunfado, de lo que ya ofrecí un resumen histórico, con la afirmación nebrisense de que "en la edad de nuestros abuelos" se decía cibdad y "después nosotros la $b$ boluimos en $u$ vocal" (2002: 32-34, 368, 425). En nuestro legajo de 1492 solo hay ciudad, deudos, deudores, y raro es el término con - $b$ en los textos inquisitoriales, lo cual sugiere que los judíos aragoneses y de distintos dominios del norte peninsular se verían asimilados a los de otras regiones en la nivelación del exilio, o que mantenían el uso tres o cuatro décadas antes vigente en esta región.

Reconocía Nebrija la coexistencia de ge lo y se lo, innovación entre los más cultos ya dominante en el mediodía peninsular y que el gran humanista ennoblece con su uso, también de empleo único para Juan de Valdés, si bien en corpus eclesiástico conquense pocos años anterior a su Diálogo la forma etimológica y la innovadora se reparten con similar frecuencia sus registros, cuestión de diversidad sociolingüística por tanto, mientras el español norteño manifiesta un mayor apego por el resultado etimológico que el del centro y sur, con al menos cuatro testimonios de ge lo en el testamento de Juan de Coloma. Igual que Juan del Encina y Lucas Fernández, norteños, no solo coinciden con los aragoneses en la vocalización de /-b/ (caudal, codicia, codo), sino en el mantenimiento, no regular, de ge lo, con que el extremeño Torres Naharro connota el lenguaje villanesco. 
En cuanto a los compuestos nosotros, vosotros, son de plena aceptación nebrisense, si bien este autor aún conjuga los verbos con nos y vos sujetos, de los que hay todavía testimonios en el español del siglo XVI, no así en Aragón, donde la composición pronominal ya se documenta latinizada a principios del XIII y triunfa antes que en Castilla. Respecto del vos átono, lo conserva Nebrija ("pésavos"), bien que advirtiendo que se puede decir o escribir "él vos dixo" y "él os dixo", preferida la variante moderna por Valdés. Igualmente domina en Juan del Encina os, predominio morfológico que se rompe para evitar con vos la sinalefa en "viéndovos quedar mi vida", mientras Torres Naharro, de acuerdo con su naturaleza regional, lo mismo que Nebrija, es reiterativo en la conservación del tradicional vos átono ${ }^{39}$.

En la variación lingüística de la época competían los etimológicos do, estó, so, vo con las formas añadidas de una /-i/, y el uso tradicional en la hora de la expulsión iba relegándose al habla rústica. Era Nebrija afecto al rasgo moderno, indicando sin embargo que "algunas vezes por hermosura añadimos $i$ sobre la $o$ ", y en línea con la apreciación nebrisense la valdesiana es que "yo so, por yo soy, dizen algunos, pero, aunque se pueda dezir en metro, no se dize bien en prosa". Se hallaba muy extendida en el castellano central y meridional la solución innovadora, pero en el corpus conquense coetáneo de Valdés alternan estó y estoy, de nuevo la diversidad sociocultural, y en los cultos poetas salmantinos citados abundan los verbos de presente en $-y$, con preferencia sobre las formas antiguas, exclusivas con numerosos registros las etimológicas en Coloma.

En lo concerniente al mantenimiento o pérdida de la/-d-/ de las formas verbales llanas, puede darse el texto curialesco de 1488 con predominio de la primitiva evolución (agades, fagades, llamades, llevedes, vayades), frente a la solución moderna (entendáis, procedáis, sois), en el que curiosamente es constante el vos átono ("vos sea mostrada", "vos den e paguen", etc.), por más que el panorama general fuera de próximo triunfo de la tendencia innovadora. Nebrija $(1492 / 1980: 238,250)$ defiende por el uso la pérdida de esta consonante en la conjugación (avéis, sois, vais), sin desconocer que el rasgo antiguo pervivía, "en la segunda persona del plural las más vezes hazemos syncopa", lo mismo que Valdés, este con sistematicidad (en él todo es avéis, satisfagáis, veis), una vez más en contraste con el eclesiástico

39 En corto espacio textual, Pedro Cit, converso, dice "quitárgelo", "gelo dixo", "gelo havía dado" y "quién se lo dava"; poco antes, Jehuda Abenardut diría: “¿de qué os marabilláis?”, "ruégovos que me tengáis secreto" "no miréis" $(438,440)$ y Mossé Catorçe "gelo demostrava" (506). De los datos y cuestiones de este párrafo y del siguiente en otra parte me ocupo (2002: 99-100, 425-428). 
texto conquense, en cuyos interrogatorios es predominante esta evolución, asimismo resultante en querés, tenés, tomés, traés, y pocas reminiscencias del tipo arcaico (avedes, bedes). Por su parte, Juan del Encina muestra su constante apego a la solución evolutiva moderna, lo mismo que el redactor aragonés de nuestro Texto IV (avéis, deis, fagáis, fazéis, guiéis, reboquéis), $\mathrm{y}$ en testimonios inquisitoriales aunque se halla algún ejemplo como "bedes aquí este cuerpo" (278), se encuentran podís 'podéis' y enreys 'enredéis' (513), con muchas más formas $\sin /-\mathrm{d}-/$, y muy recurrente empleo del pasado vide, vido.

5.2.2. Esta selección del acervo gramatical sacado de España por los judíos, con variaciones que luego reacomodarían en la diáspora, demuestra la diversidad sociocultural y diatópica del castellano de finales del XV, a la que se debe atender para atisbar lo que pudo ser el habla romance de las comunidades hebreas en la Península y comprender la formación y consolidación del judeoespañol en el exilio. Si Nehama en la entrada ainda recoge ay como impersonal de tiempo con la frase "ainda ay poco tiempo", y en los años ochenta del XIX en Salónica se escribía "succeso obtenido hay seis meses" (Romero 1969: 211), conviene saber que con igual valor usaba esta forma en América un natural de Carmona el año 1803, "pue ai muchos años que no nos bemos", y como auxiliar en texto canario de 1686, "qué se ay hecho dellos" (Frago 1999: 299), también que el uso perdura en algunas zonas andaluzas ${ }^{40}$. De igual modo, el empleo judeoespañol de vos átono, encuentra relación histórica con el español meridional (Nebrija y Torres Naharro), y moderna con registros como "ustedes vos vais", conexión que asimismo se verifica respecto de las desinencias -ates, -ites, de gran difusión en hablas rurales andaluzas ${ }^{41}$.

El masculino siñal de los sefardíes salonicenses responde al catalanismo y aragonesismo morfológico de señal, e indudable connotación aragonesista tiene el trueque de los temas de presente y de pasado, plasmado en un supido de la Salónica del XIX y en numerosos registros de Nehama como embolvido, supiendo, tuvido, tuviendo, uvido 'habido', con no pocos testimonios de

\footnotetext{
40 En muchos puntos del dominio andaluz pervive hay un año que, según el mapa 1856 del ALEA.

${ }^{41}$ ALEA, mapas 1792, 1793 para el sufijo -ates, -ites. Los mapas 1823, 1828, 1829, 1833 para vos átono ("vosotros vos vais", "vosotros vos reís"), y Mariano Franco Figueroa, filólogo y amigo, me informa que en localidades onubenses cercanas a Portugal, así Santa Bárbara de Casa, el empleo de vos se mantiene en personas mayores y en algunos hablantes más jóvenes. Vide, vido también tienen registros en el habla popular andaluza.
} 
judíos y conversos aragoneses, como los de estuviendo (514, 520), sopido 'sabido' (408), tubiendo (426), fenómeno del que un haviera hay nada menos que en Coloma y más ejemplos en Marcuello, en cuyo Cancionero se registran varios daron 'dieron' y pusiendo, tuvido, tuviendo, casos todavía corrientes en hablas rurales de Aragón. La solución judeoespañola del imperativo con enclítico tomaimus 'tomadnos', yamaivus 'llamaos' (Zamora Vicente 1967: 358), aparece en un daynos 'dadnos' dicho en 1488 por una conversa rural (513), de mayor implantación en hablas leonesas.

El romance aragonés tuvo diferenciación morfológica para el femenino de adjetivos invariables (grisa de gris, verda de verde), y, en el campo judeoconverso, la Montalegra era nombre de confesa de Calatayud, como Jaima judía de Zaragoza datada c. 1405 (Blasco Martínez 1991: 98), y por entonces del nombre de varón Haimo Hain en la misma aljama existió una Haina Çarfatí (Blasco Martínez 2006: 72-76), estando en testimonios inquisitoriales retreta, de retrete ("huna retreta siquiere estudio"), y meyesa, de mege 'médico' con y para la prepalatal fricativa sonora, en la prohibición para ejercer varias profesiones a cristiana nueva condenada, que "ni pueda ser meyesa, apothecaria, corredora, ni tener officio público alguno" (208), sin olvidar la variación albondaquillos-albondaquillas (cfr. 4.2.).

\subsection{LÉXICO Y DIALECTALISMO}

5.3.1. En perspectiva medieval caler 'convenir' no puede considerarse catalanismo exclusivo como Nehama piensa, pues aunque su uso castellano ya declinaba desde finales del XIV, en los textos de la Inquisición aquí considerados tiene decenas de registros, y no poca pervivencia actual en esta región, "hoy sobrevive en aragonés y en judeoespañol" $(D E C H)$, más bien español de Aragón; ni se sostiene el exclusivo italianismo de coda 'cola de animal', pues antes de la diáspora ampliamente se atestigua dicha voz en este dominio, donde perdura su uso y el de escodar. De igual modo, la documentación aquí manejada asegura el arraigo del consumo de confites entre los judíos hispanos, igual que el de rosqueta, en Alcañiz 'mona de pascua', y el comer pan turrado; todavía, también en las vecinas hablas navarras, turrada es 'rebanada de pan tostado, con aceite (sal y ajo)'. Se ha señalado el aragonesismo de royo en Salónica, Zamora Vicente extiende su uso a Bosnia, y en Macedonia el de fiemo 'basura'. Parecida ascendencia dialectal tendrá chuflar 'silbar', al menos con el criterio de la gradualidad, reforzado por el diminutivo chuflet, e indudable precedente aragonés tiene lonso 'oso', con artículo aglutinado, extendido por todo el judeoespañol oriental, de cuya vitalidad dan idea sus derivados (lonsón, lonsedad en Nehama) y sentidos figurados. 
5.3.2. Un dialectalismo sefardita puede no ser de única procedencia, pues catalán y aragonés comparten la de esmolar 'afilar', mangrana 'granada', melsa 'bazo' y esmerçar 'invertir, prestar', del vocabulario salonicense, recurrente en el testamento de Juan de Coloma. La confluencia léxica puede darse desde territorios alejados, así la de escuma del catalán y del portugués, perdiéndose espuma en judeoespañol, o la de renda 'renta', para Nehama portuguesismo, pero que en 1492 tenía gran vitalidad en Aragón y está muy presente en el corpus testamentario del principal notario de Fernando el Católico.

El salonicense fornaya 'horno de cocina', en la Biblia ferrarense "forno y fornallas", responde al luso fornalha 'pequeño horno', y los portuguesismos con su apoyo gallego enriquecieron el conjunto dialectal judeoespañol con voces como ainda, alfinete, bico, buraco, cadenado, concho, embirrarse, enguyos, fadu, fégado, froña, fulí y tantas más, constituyentes del grupo seguramente más numeroso del léxico que no procede del castellano. Aunque este sea la base fundamental de las hablas sefarditas: términos que en la Península se anticuaron, otros que en el exilio mudaron de significado o continuaron coincidentes con el español moderno, pero con su característica pronunciación y con frecuentes alteraciones vocálicas y consonánticas, además de los casos de innovación judeoespañola, como negrigura 'desgracia, maldad' y yavedura 'cerradura'.

La fonética de este léxico orienta sobre la composición demográfica y lingüística de las comunidades sefarditas, verbigracia por el etimológico/fl-/ de flama, el mantenimiento de /-b/, según el correspondiente panorama arriba descrito, con sus resultados /-b/ y /-v/, la precedente geografía del grupo /-mb-/, afortunado en la koineización sefardita (lamber, lombo, palomba), o la aspiración de /f-/, en conexión histórica con amplio dominio peninsular de este fenómeno a finales del XV (parte del astur-leonés, y extremeño, castellano-manchego y andaluz), en diferentes grados de convivencia con la conservación de la consonante latina y con su pérdida /fermóza, hermóza, ermóza/.

\section{6. ¿EXISTIÓ UN JUDEOESPAÑOL PENINSULAR? EPÍLOGO}

6.1. Con esta pregunta enfocó Simon Marcus una investigación en 1962, se la han planteado más o menos abiertamente otros estudiosos y realmente es inevitable hacerla, pues por azar no pudieron formarse las hablas sefarditas, con el heterogéneo conglomerado lingüístico que las constituye, solo 
apelando a la existencia de muchos elementos de tal variedad idiomática antes de la expulsión, y a la tradición imperante en las comunidades hebreas, importantísimo factor de su historia, desde luego. Ningún tratamiento de esta cuestión le ha dado respuesta suficiente, concretada con bastantes datos empíricos. Parece natural que algún nexo común hubo entre las comunidades judías peninsulares, un sustrato hispánico ideológico y de caracterización lingüística que permitiera que las diversas juderías de la diáspora, con sus iniciales fuertes diferencias regionales y su gran dispersión geográfica, pudieran mantener una cierta unidad identitaria que conjugaba lo uniforme con lo discordante.

Es así importante aclarar el grado de adaptación al romance de los judíos en 1492, sobre todo en los dominios sujetos a castellanización, así el aragonés, donde Conejo se apellidaba uno de Zaragoza, Catorce uno más de Calatayud y "Aguas Truchas alias Barro" otro de Huesca. Y si por su sufijo el apodo Bonillo del cristiano Joan Bueno tiene especial clave lingüística (cfr. 4.1.), de semejante interés es la sufijación romance de nombres hebreos, así la de Abraymico, niño judío oscense, y la de Jucico Paçagón, bilbilitano convertido después de la expulsión, o que al rabino Bienvenís Arruetí hacia 1440 le dijeran dos conversos: "bien no puedes comer, Bienvenisico" (526).

$\mathrm{Si}$ el castellano culto del cuatrocientos presentaba claras diferencias diatópicas en su evolución, mayores que las de posteriores siglos, mal podía darse un hablar romance homogéneo en las juderías, con sus diversidades sociales y culturales, urbanas unas y otras rurales, de todos los dominios peninsulares. Pero sí hubo usos comunes en la fonética y en la pronunciación del castellano antiguo, que revela la onomástica hebrea y algunas voces romances (corneya, meyesa). En las mismas fuentes inquisitoriales se registran amatu, culantru y oréganu en la citada pieza jocosa, un repetido duelu, royu y el apellido Churchullu, además de caldeu, "otro (libro) con cubierta vert, nombrado caldeu de Ysayas" (López Asensio 2009: 137), además de /-i/ por/-e/ en ponti 'ponte', en el nombre de judío oscense Ponti, y en el remedo burlesco "avanti, christiani...", Christiani fue apellido adoptado por un judío oscense a finales del XV. Todo ello junto a coincidencias léxicas con el judeoespañol de la diáspora y posibles muestras de la tendencia a la marca morfológica del femenino de adjetivos invariables (cfr. 4.2.). Para Zamora Vicente (1967: 352) los referidos cierres vocálicos en el grupo sefardí occidental proceden "de los dialectos del norte de España o de Portugal", aunque la documentación aragonesa no aprueba esa hipótesis, sino que apunta a coincidencias del este con el occidente peninsular, que, de manera más evidente en el caso de Aragón, cuyas hablas desconocieron la inflexión de /-e, -o/, necesariamente hubo de deberse a un contacto de hebreo y romance en las juderías. 
De hecho, en el estudio de los códices de don Sem Tob se encuentra atantu, dañu, derechu, enemigu, vezinu, etc., numerosas vacilaciones vocálicas y diptongaciones anómalas, tendencia a representar la palatal nasal como /ni/, danio, enganio, confusiones de sibilantes como en la Biblia de Alba y en los documentos aragoneses (açcona 'azcona', çerbiçial) y mos por nos, además del femenino granda de grande, pero que no relacionó con el judeoespañol Alarcos Llorach (1951). E indicio de afinidades iberorrománicas es el verbo sabadear, superviviente en portugués europeo y del Brasil con sentido de 'guardar el sábado a la manera de los judíos', que en Castilla significó 'rezar como los judíos', con numerosas apariciones en los documentos de la Inquisición en Aragón, estas de 1487 y 1488, por ejemplo: "estuvieron unos cinquo o seys judíos de senyal alderredor de una cama donde estava echado un mochacho enfermo, cantando en ebrayco e sabadeando" (396), "como fazía la dicha oración, yva sabadeando con la cabeça" (513), "estavan sabadeando, remeciendo la cabeça e rezando en ebrayco" $(548)^{42}$.

6.2. Ni mucho menos era completamente desconocido el hebreo en las aljamas de Aragón, aunque de las mujeres sabemos que muchas necesitaban la lectura de textos bíblicos en un romance ${ }^{43}$ que con diferencias normativas y de competencia también conocían los varones, no todos en su lectura y escritura, desde luego sí individuos como el Rabí Manuel y el mercader Salomón Atortox de la judería rural aragonesa. Pero los cristianos no los entendían cuando entre ellos hablaban "con la gorga" 'gorja, garganta' (Sesma Muñoz 1992: 86), alusión a una pronunciación gutural también percibida en otras partes de España, motivo del refrán No digas, judio, "ax", con la adición que deshonras tu "linax" (Correas 1627/1967: 395), interjección aj que con $u j$ en Salónica forma la locución estar en aj y uj 'caer en pesares y angustias' (Nehama 1977: 16). Naturalmente, en cuanto a su dominio del romance, contaban las profesiones que desempeñaban y que

42 Todos estos testimonios van contra cristianos nuevos y los deponentes en muchos casos lo eran. El verbo en cuestión se creó, pues, en aquel amplio medio social en el que confluían conversos y judíos con el uso del romance, empleado ya en una traducción bíblica de hacia 1300 y con prolongación en el siglo XVI: Cfr. Cantera Montenegro (2007: 31), Pérez Alonso (2012).

43 Quizá tenga que ver con esto que algunas judías para sus testamentos acudieran al notario cristiano y no al de la aljama (Blasco Martínez 1991: 78-79), también que dominaban el romance. 
en general eran vistos por los cristianos como de superior nivel cultural, muchos amantes de los libros y de la escritura, tradición a la que alude el refrán Cuando los judíos no tienen dineros, revuelven papeles de padres $y$ agüelos, lo cual explica que quienes fueron en su comunidad "letrados" a poco de su conversión, uno de ellos hacia 1460 leía la Visión delectable (260), podían ser clérigos, notarios, juristas o miembros de la alta burocracia.

Por ello en judeoespañol no todo es vulgarismo, sino que también en él se encuentran rasgos cultistas, así el devenir que ya usó Coloma y el mismo Antón Francés (Texto II), también en coincidencia con el protonotario fieldad, lealdad, piadad, santedad, asimismo dende, empués y estonces, las variantes ansí-así (no ansina), mesmo-mismo o dalde y terné, igualmente presentes en buenos autores del XV. El doblete malino-maliño (Nehama) es de uso corriente en Cristóbal de Castillejo, Valdés prefería mañifico a magnifico, y voces hay en este conjunto dialectal de la escribanía, del estamento judicial y del notariado: los latinismos ameliorar, amelioramiento, mobilia 'conjunto de muebles', véndida 'venta', además de corredor, escribano, fiador, oidor, procurador (percurador, percurar), sinatura. También hay grupos consonánticos cultos (fluktuasión, oktobre, observar, obtener), junto a muchas simplificaciones, y los sefarditas se han manejado con ciertas valoraciones socioculturales del lenguaje, recuérdense el sentido dado a gayego y la preferencia de erida y umo sobre ferida, fumo. Asimismo se consideran formas "nobles" esfuegra, fuego, fuente frente a eshuegra, huego, huente con /f/ velarizada. Y de judíos cultivados, que a Sefarad llamaban "nuestra España", es la traducción de la Biblia de Ferrara, en una lengua de ribetes arcaicos respecto de la de 1492, pero, componente ladino aparte, en no pocos aspectos coincidente con el buen español escrito a finales del XV y comienzos del XVI, en todo caso bien distinta a la que se fraguaba en las juderías de la diáspora, cuestión de la que se ha ocupado Minervini (2002).

6.3. Llega un destierro al que se ven abocados judíos de todas las regiones españolas, a los que se unirían muchos portugueses, de esta nación una línea migratoria se haría preponderante en Amsterdam y región hanseática, Hamburgo en especial, y en la cuenca mediterránea desde Italia a Turquía, sumado el norte de África desde Marruecos, se forja un proceso de nivelación lingüística en el que se comparten rasgos léxicos antes diatópicamente diferenciados, además de aspectos del castellano importantes en el nivel gramatical, con distintos grados de implantación territorial en 1492, de los que variantes llamadas a desaparecer perdurarían entre los sefarditas: 
a) Nos, vos para sujeto plural y complemento con preposición, con apoyo de los originarios del dominio leonés, donde aún pervive su uso, y sobre todo de gallegos y portugueses.

b) Conservación de vos átono, con igual refuerzo diatópico, sumado el de hablantes andaluces y extremeños (v. n. 41).

c) Los etimológicos do, estó, so, vo, rechazados por Valdés, “dizen algunos..., no se dize bien en prosa", en la fase más arcaizante de esta evolución, recurso para la rima en Juan del Encina y Lucas Fernández, para Torres Naharro también para la caracterización del aldeano, que el refranero corrobora: Tú te estás i io me estó, ni tú me lo pides ni io te lo do (Correas 1627/1967: 508), con comprobable apoyo del contingente portugués sumado al sefardismo.

d) Mientras en el sur socioculturalmente triunfaba se lo, Valdés repudiaba ge lo, la forma antigua se mantenía en el español de Aragón y en los poetas salmantinos; pero si Nebrija ponía en alto ciudad y se lo, los textos notariales de su región conservaban cibdad y ge lo, que también tendrían predicamento popular. Entre los sefarditas se impuso la solución innovadora gramatical, en tanto que se aferraban a los antiguos cabdal, cibdad, de geografía lingüística menos uniforme, repartida incluso en un mismo territorio con caudal, ciudad en la hora de la expulsión.

e) Conservación de la /-d-/ en formas verbales llanas (sabedes, tenedes). Decadente a finales del XV y pronta a refugiarse en hablas rurales; en algunas leonesas aún pervive (Borrego 1996: 146).

6.4. Los sefarditas parten con heterogéneo bagaje, que tenderá a nivelarse en el exilio, con cultismos y un gran número de vulgarismos guardados cuasi religiosamente, así mos por nos átono, que existía en España (mos, mosotros, muestro en Torres Naharro) y solo se mantiene en dispersas reliquias dialectales que llegan por el occidente hasta Andalucía, fijándose lexicalizadamente alteraciones vocálicas y consonánticas y produciéndose otras (godro 'gordo', pedrer 'perder', sodro 'sordo'), dándose también un gran impulso a la prefijación, siendo particularmente representativo de esta koineización el que se hicieran sistemáticos usos que en origen no habían alcanzado total uniformidad, que seguramente tampoco se daría en el habla de todos los judíos peninsulares, aun contando con el tradicionalismo que los caracterizaba, pues, entre otras cosas, se lo era innovación en busca de su estandarización en el siglo XV.

En el uso judeoespañol se fundirían cojombral 'campo plantado de pepino' y niñeta 'niña del ojo' (Nehama). Para el primero habrá que mirar 
al andaluz cojumbral 'plantío de legumbres' y al extremeño cojombriyo $(D E C H)$, para el segundo al aragonés, con presencia en la Biblia de Ferrara. Porque la tradición se enlaza de las hablas a los textos, y en esta monumental traducción resuenan voces de la Biblia de Alba, como afermosiguar, alsación 'sacrificio', doladicio 'ídolo', profundina 'abismo', sombajar 'engañar' (sombair, sombayer), con traslación al habla sefardí (v. n. 6), cuyas fuentes orales y escritas en acertada apreciación de Hassán son "un precioso archivo dialectal hispano" (1988: 131), lo que obliga a tener una visión lo más ajustada posible de la diversidad diatópica hispana anterior a la expulsión, como demuestran los aragonesismos fiemo y royo, o la voz del mismo tipo regional livianus 'pulmones' conservada en Serbia. Naturalmente, asimismo importa la difusión de usos propios de los hebreos de los distintos dominios peninsulares, de modo que los registros aragoneses de términos en $-i$ y $-u$ (avanti, ponti, culantru, oréganu, etc.), con sus correspondencias en Sem Tob de Carrión, impiden considerar su presencia en la diáspora simple impronta del occidente peninsular. No disponía de esta perspectiva documental Zamora Vicente, tampoco Alarcos Llorach, ni Penny (1992), aunque este autor todavía creía en la distinción de sibilantes sordas y sonoras en 1492, y sin ninguna concreción se refiere a "la prestigiosa variedad toledana del español", mero tópico para el ahorro de documentación.

A este respecto, importa saber que la movilidad judía sospechada por Várvaro efectivamente fue intensa, lo que aseguran apellidos de hebreos como Francés y Gascón, o Çarfatí 'de Francia', conocido en Castilla y Aragón, o que artesanos sederos y de otros oficios se movían libremente por todos los territorios hispánicos. También que no pocos hebreos castellanos tras las matanzas de 1391 y siguientes persecuciones se trasladaron a Aragón, igualmente convertido en refugio para muchos conversos castellanos y leoneses antes de la implantación del Santo Oficio en este reino. Asimismo, que 150 judíos portugueses en 1394 llegaron a Mallorca (Baer 1981: 404), asentados otros en aljamas aragonesas, contando también con la emigración de Castilla a Portugal de judíos que escapaban de los desórdenes populares y del acoso inquisitorial. De donde que a las diferentes comunidades hebreas no les debieron de resultar del todo ajenas algunas peculiaridades de la amplia y compleja geografía lingüística peninsular.

6.5. Conviene igualmente no perder de vista a la numerosísima masa de conversos, de la que durante mucho tiempo se irían nutriendo las comunidades sefarditas de la diáspora, con aumento también de las que se formarían en América. No es en vano, así, fijarse en lo que fue y supuso la figura de micer Gonzalo García de Santa María, relevante ejemplo del nivel 
cultural de tantos cristianos nuevos, como los poderosos hermanos Gabriel y Luis Sánchez, o en que al rabino de la pequeña judería de Magallón pidieron "les escribiera conjuros hebreos" (1.2.4.), lengua de la que los procesos inquisitoriales esmaltan muchos testimonios, por ejemplo, en el corpus Judioconversos, "abréis dezir tal pizmonnim y tales oynas quando se perdió la Casa Sancta", "pazmom, que quiere dezir prosas; quinos, que quiere dezir endechas" (507-508), continuamente hamin, y, en desprecio a una mujer, "engányala, que buena behema es, que quiere dezir, tornado de ebrayco en romance, bestia" (430), dominio lingüístico que a uno le permitía burlarse de los cristianos llamándolos hantor, "que quiere dezir asno, y fablando algunas palabras en ebrayco, las quales le demandavan aquellos obreros judios" (432), por tanto que ignoraban los hebreos iletrados. Testigos hubo que vieron a un converso "sabadiando de la cabeça e fablando e gorgeando de la boca", y a un matrimonio de cristianos nuevos y una judía que en casa de esta "favlaban todos tres, que no los entendía" (Marín Padilla 1983: 330), en consonancia con la observación de que los cristianos no entendían a los judíos cuando entre ellos hablaban "con la gorga" (6.2.), como Révah puso de relieve "surtout les parlers des Juifs conversant entre eux" (1970: 238240). De manera que de los que usaron su ancestral lengua y el romance derivan inflexiones vocálicas como las del cantar (con culantru y oréganu) con que los mozos de Daroca hacían burla de los judíos de su pueblo (4.2.).

La simple existencia de estos testimonios aragoneses necesariamente se contrapone al pretendido occidentalismo sefardita del mismo fenómeno fonético, y junto a ellos deben considerarse las correspondientes atestiguaciones de los Proverbios morales, que no se han tenido por resultado de bilingüismo hebreo-romance, y en la obra de Sem Tob de Carrión Aíbto 'Egipto', según sus editores en la literatura sefardí Aifto, Ayifto, uno de los pocos "rasgos judíos" en el manuscrito del sabio rabino (1998: 56), un judaizante lo repetiría en América a principios del XVII, muestra una pérdida de la mediopalatal $/ y /$ que en semejante contexto vocálico es asimismo propia de hablas populares hispánicas. El rastreo textual ofrece inopinados hallazgos convenientes a la historia del judeoespañol, y el estudio de juderías rurales que en 1492 aportaron al exilio contingentes tal vez mayores que las aljamas urbanas, con lo que esto supone de refuerzo del factor popular de sus hablantes. La de Magallón ofrece noticias de diversa índole, que arriba se han ido desgranando, de no poco interés la concerniente a su rabino astrólogo y al mantenimiento del hebreo en alguno de sus integrantes, pero también al sentimental arraigo local de sus miembros o descendientes, cuatro de los cuales vivían en Huesca en 1475 con el apellido Magallón (2.3.).

Así, tirando del hilo local y urbano se puede llegar a la enjundia del sefardismo. Efectivamente, Baer $(1981: 541,611)$ localiza en Huesca c. 1460, 
y por un proceso inquisitorial en 1489, a los rabinos Abraham Almosnino e Ishac Cocumbriel, abuelos del célebre rabino de Salónica Mossé Almosnino, para Hassán y Romeu (1992: 162-163, 165) descendiente de expulsados de Jaca, nacido en la ciudad griega en primera o segunda generación y autor de la Crónica de los reyes otomanos, "la única obra literaria sefardí conocida del siglo XVI de libre creación". La judería jacetana hasta nueve varones de este apellido tenía en 1377 (Romano 1982: 31-32), y en la oscense un propietario urbano hubo de nombre simplemente Almosnino el año 1475, pero sin noticia del rabino del mismo apellido (Benedicto Gracia 2003: 233), precisamente porque el rabí Abraham Almosnino figura el año 1478 contratado como çofer por la aljama de Calatayud (López Asensio 2016: 236). Los datos familiares sugieren que el nacimiento salonicense del sabio rabino debió de ser en primera generación, con nombre no solo aragonés, almosna 'limosna' de continuo uso en Juan de Coloma, sino con un castellano necesariamente matizado de aragonesismos, que seguramente podrán rastrearse en su obra.

\section{CODA}

Eran arcaizantes y también familiarizadas con el elemento popular hispano muchas gentes de Sefarad, de ahí su tradición en el cancionero, en su riquísimo acervo de refranes y giros fraseológicos, con centenares de muestras en el diccionario de Nehama y en otros repertorios; en la lengua también, pues de otro modo no se explicaría su mantenimiento del tipo morfosintáctico la mi madre (portugués a minha mae), y tantos otros herederos del castellano de 1492 y de sincronías precedentes. La tradición del magzór catalán se conservó después del éxodo en las sinagogas de Oriente en fieles originarios de Cataluña (Nehama) y el portugués folar 'regalo pascual' pasó a ser 'dulce en forma de horca que se regalaba a los muchachos en la fiesta de Purim', y ya en el siglo XVI la chiquillería, de ascendencia portuguesa o no, disfrutaba en Turquía su Sabat de folares con toda clase de golosinas con que se la obsequiaba. Esa tendencia al tradicionalismo de la diáspora quizá se vería reforzada por comunidades hispano-hebreas en el exterior preexistentes a la expulsión, pues ya en 1341 habían llegado algunos judíos hispanos a Sarajevo, muchos más a mediados del siglo XV (Nezirovic 1998: 562), además de anteriores emigraciones a Marruecos. Y en 1495, Beirut contaba con nutrido grupo de hebreos de origen peninsular, quizá antes asentados en esta ciudad, en casa de cuyo rabino, Yosef Saragosa Sefardí, estuvo alojado un joven italiano que relata su viaje a Jerusalén. (Motis Dolader 1990: 299) 
El amor casi incomprensible de muchos sefarditas a la patria perdida haría que entre los desterrados hubiera quienes llevaran consigo la llave de la casa obligados a cerrar, por añoranza celosamente conservada por algunos durante generaciones, lo que no ha sido solo pura leyenda o mero mito histórico, según en el Centro sefardita de Santiago de Chile se me dijo y de lo que alguna constancia personal tengo ${ }^{44}$. En cualquier caso, es la admirable tenacidad en mantener el legado de sus mayores la clave maestra de fraternidad entre sefarditas y los que integramos la gran familia hispanohablante, de la antigua Sefarad a su ancha extensión allende los mares.

\section{REFERENCIAS BIBLIOGRÁFICAS}

Alarcos Llorach, Emilio. 1951. La lengua de los Proverbios morales de don Sem Tob. Revista de Filología Española 35: 249-309.

Alighieri, Dante. 1982. De vulgari eloquentia. Edición de Matilde Rovira Soler y Manuel Gil Esteve. Madrid: Universidad Complutense.

Alvar, Manuel con la colaboración de A. Llorente y G. Salvador. 1961-1973. Atlas lingüístico y etnográfico de Andalucía. Granada: CSIC (ALEA).

Asensio, Eugenio. 1960. La lengua compañera del imperio. Revista de Filología Española 43: 399-413.

BAER, YITZHAK. 1981. Historia de los judios en la España cristiana. Madrid: Altalena Editores. Benedicto Gracia, Eugenio. 2003. La aljama de los judíos de Huesca a fines del siglo XV: una nómina de casatenientes de la judería de 1475. Sefarad 63: 227-236.

Benítez, Fernando. 1962. Los primeros mexicanos. La vida criolla en el siglo XVI. México: Ediciones Era.

44 De aquella entrañable comunidad hebrea con particular afecto recuerdo a Raquel Gateño Palombo, dama de un sefardismo vivo, nacida en América poco después de emigrar sus padres de Esmirna en 1920. Por otro lado, se ha publicado el recuerdo de dos bilbilitanos que, en la década de 1960, un mes de julio atendieron a un viajero que se presentó como profesor de la Universidad de Tel Aviv, preguntando por la Plaza de la Figuera, así se menciona en textos de la Inquisición, hoy de la Higuera, donde aseguró se hallaba la casa de sus antepasados. Varios circunstantes lo condujeron a ella según sus indicaciones y, mientras era atendido por la dueña, les describió su interior tal como el recuerdo familiar se lo había transmitido, interior de su relato no muy distinto del actual. Luego, sacando una llave de canutillo, hizo el ceremonioso gesto de abrir la puerta y entró de nuevo (Casado López 2017). Pues bien, este personaje entabló amistad con mi suegro, Salvador Amada Sanz, a la sazón profesor del Instituto de Calatayud y abogado, a quien visitó en los varios viajes que haría a la tierra de sus mayores, de uno de los cuales Blanca guarda como preciada prenda un antiguo ajedrez con motivos hebreos. 
Blasco Martínez, Asunción. 1991. Mujeres judías zaragozanas ante la muerte. Aragón en la Edad Media 9: 77-120.

2006. Presencia y discriminación de los judíos en la elaboración de tejidos. Aragón en la Edad Media 19: 63-82.

Borrás Gualis, Gonzalo Máximo. 1969. La liquidación de los bienes de los judíos expulsados de la aljama de Calatayud. Sefarad 29: 31-48.

Borrego Nieto, Julio. 1996. Leonés. En Manuel Alvar (director). Manual de dialectología española. El español de España, pp. 139-158. Barcelona: Editorial Ariel.

Cabezudo Astrain, José. 1955. La expulsión de los judíos zaragozanos. Sefarad 15: 103-136.

Cantera Montenegro, EnriQue. 2007. El pan y el vino en el judaísmo antiguo y medieval. Espacio, Tiempo y Forma. Serie III, Historia Medieval 19: 13-48.

Casado López, Manuel. 2017. Noticia de un viajero sefardí en Calatayud. Centro de Estudios Bilbilitanos (27.06.2017).

Corominas, Joan y José A. Pascual. 1980-1991. Diccionario crítico etimológico castellano e hispánico. Madrid: Editorial Gredos $(D E C H)$.

Correas, GonZalo. 1627/1967. Vocabulario de refranes y frases proverbiales. Editado por Louis Combet. Burdeos.

Covarrubias, Sebastí́n De. 1611/1979. Tesoro de la lengua castellana o española. MadridMéxico: Ediciones Turner.

De las Cagigas, Isidro. 1929. Libro verde de Aragón. Madrid (LVA).

De la Torre, Antonio. 1951. Documentos sobre relaciones internacionales de los Reyes Católicos, III. Barcelona: Consejo Superior de Investigaciones Científicas.

1962. Documentos sobre relaciones internacionales de los Reyes Católicos, IV. Barcelona: Consejo Superior de Investigaciones Científicas.

ENCINA, JuAn DEL. 1496/1989. Cancionero. Edición facsímil. Madrid: Real Academia Española.

Frago, Juan Antonio. 1993. Historia de las hablas andaluzas. Madrid: Arco Libros. 1999. Historia del español de América. Madrid: Editorial Gredos.

2002. Textos y normas. Comentarios lingüisticos. Madrid. Editorial Gredos.

2012. Lecciones lingüísticas en versos mexicanos de la Independencia. Boletín de la Real Academia Española, 92: 59-84.

2018. La lengua del testamento de Juan de Coloma. Entre el medievalismo y el humanismo renacentista. Cuadernos de Estudios Borjanos 61: 219-250.

GonzÁlez Ollé, Fernando. 1987. Primeras noticias y valoraciones del andaluz. Boletín de la Real Academia Española, 67: 347-387.

Guitarte, Guillermo L. 1983. Siete estudios sobre el español de América. México: Universidad Nacional Autónoma de México.

Hassán, IAcob M. 1988. Sistemas gráficos del español sefardí. Actas del I congreso internacional de historia de la lengua española, pp. 127-137. Madrid: Arco Libros, I.

Hassán, IAcoB M. y Pilar Romeu. 1992. Apuntes sobre la lengua de la Crónica de los reyes otomanos de Moisés Almosnino según la edición del manuscrito aljamiado del siglo XVI. Actas del II congreso internacional de historia de la lengua española, pp. 161-169. Madrid: Pabellón de España, II.

Lazar, Moshe (ed.). 1996. Biblia de Ferrara. Madrid: Biblioteca Castro.

López Asensio, Álvaro. 2009. Sabiduría judía de Calatayud y Sefarad. Zaragoza: Libros Certeza.

2016. Judioconversos e Inquisición en Calatayud. Zaragoza: Editorial Certeza (Judioconversos).

Lleal, Coloma. 1995. Aljamías hebraicoaragonesas (siglos XIV-XV). Barcelona: Universitat de Barcelona. 
Maia, Clarinda de Azevedo. 1997. História do galego-português. Estado linguístico da Galiza e do noroeste de Portugal desde o século XIII ao século XVI. Coimbra: Fundação Calouste Gulbenkian.

Marcuello, Pedro. 1987. Cancionero. Edición de José Manuel Blecua. Zaragoza: Institución Fernando el Católico.

Maquiavelo, Nicolás. 2012. Diálogo en torno a nuestra lengua. Edición de María Teresa Navarro Salazar y Ornella Castellani Pollidori. Madrid: Editorial Tecnos.

Marcus, Simon. 1962. A-t-il existé en Espagne un dialecte judéo-espagnol? Sefarad 22: 129-149.

Marín Padilla, Encarnación. 1982. Relación judeoconversa durante la segunda mitad del siglo XV en Aragón: nacimientos, hadas, circuncisiones. Sefarad 42: 59-77.

1982. Relaciones judeoconversas durante la segunda mitad del siglo XV en Aragón: matrimonio. Sefarad 42: 243-298.

1983. Relación judeoconversa durante la segunda mitad del siglo XV en Aragón: enfermedades y muertes. Sefarad 43: 251-344.

MARTínez Kleiser, Luis (comp.). 1982. Refranero general ideológico español. Edición facsímil. Madrid: Real Academia Española.

MenÉndez Pidal, Ramón. 1962. Sevilla frente a Madrid. Algunas precisiones sobre el español de América. Miscelánea homenaje a André Martinet. Estructuralismo e Historia 3 (Diego Catalán, ed.). La Laguna: Biblioteca Filológica, pp. 99-165.

Millás Vallicrosa, J. M. 1943. La aportación astronómica de Pedro Alfonso. Sefarad 3: 65-105.

Minervini, Laura. 1992. Testi giudeospagnoli medievali (Castiglia e Aragona). Napoli: Liguori, 2 vols.

2002. La formación de la koiné judeo-española en el siglo XVI. Revue de Linguistique Romane 66: 497-512.

Morreale, Margherita. 1961. El glosario de Rabí Mosé Arragel en la Biblia de Alba. Bulletin of Spanish Studies 38: 145-152.

Motis Dolader, Miguel Ángel. 1984. Documentos para el estudio de la expulsión de los judíos de Magallón. Tvriaso 5: 209-251.

1986. Los judíos de Magallón (Zaragoza) a fines del siglo XV y su expulsión. Cuadernos de Estudios Borjanos 17-18: 139-245.

1990. La expulsión de los judios del Reino de Aragón, II. Zaragoza: Diputación General de Aragón.

1992. Judíos y conversos en la raya occidental del reino de Aragón (siglos XIIXV). Borja y la raya occidental de Aragón, pp. 45-185. Zaragoza: Institución Fernando el Católico.

Narváez, María Teresa. 1981. Mitificación de Andalucía como nueva Israel: el capítulo Kaída del Andaluzziyya del manuscrito aljamiado la Tafçira, del Mancebo de Arébalo. Nueva Revista de Filología Hispánica 30: 143-167.

Nebrija, Antonio De. 1492/1980. Gramática de la lengua castellana. Edición de Antonio Quilis. Madrid: Editora Nacional.

Nebrija, Antonio DE. C. 1495/1989. Vocabulario español-latino. Edición facsímil de la Real Academia Española. Madrid: Arco Libros.

Nehama, Joseph. 1977. Dictionnaire du judéo-espagnol. Madrid: Consejo Superior de Investigaciones Científicas.

Nezirovic, Muhamed. 1998. La historia de los judíos de Bosnia de Mosse (Rafael) Atias (Zeki-Efendi). Actas del IV congreso internacional de historia de la lengua española, pp. 553-569. Logroño: Gobierno de La Rioja, II. 
Orozco, Sebastián DE. 1981. Relaciones históricas toledanas. Edición de J. Weiner. Toledo.

Penny, Ralph. 1992. La innovación fonológica del judeoespañol. Actas del II congreso internacional de historia de la lengua española, pp. 251-257. Madrid: Pabellón de España, II.

Pérez Alonso, Isabel. 2012. Sabadear: un ejemplo de la influencia de la cultura judía en la creación de un derivado romance. http://www.academia.edu/10297675/Sabadear_un ejemplo_de_influencia_de_la_cultura_jud $\% \mathrm{C} 3 \% \mathrm{ADa}$ _en_la_creación_de_un_derivado_ romance.

RÉvaH, I. S. 1970. Hispanisme et judaïsme, des langues parlées et écrites par les Sefardim. Actas del primer simposio de estudios sefardies, pp. 233-242. Madrid.

Romano, David. 1979. Aljama frente a judería, call y sus sinónimos. Sefarad 39: 347-354. 1982. Prorrata de contribuyentes judíos de Jaca en 1377. Sefarad 42: 3-40.

Romero, Elena. 1969. El teatro entre los sefarditas orientales. Sefarad 29: 187-212.

SALA, Marius. 1996. El judeo-español balcánico. En Manuel Alvar (director). Manual de dialectología hispánica. El español de España, pp. 360-377.

Secall Güell, Gabriel. 1982. Noticias de judíos aragoneses en el momento de la expulsión. Sefarad 42: 103-112.

Sem Tob de Carrión. 1998. Proverbios morales. Edición de Paloma Díaz-Mas y Carlos Mota. Madrid: Ediciones Cátedra.

Serrano y Sanz, M. 1914. Testamento de Gonzalo García de Santa María. Boletín de la Real Academia Española 1: 470-478.

Sesma Muñoz, José Ángel (coord.). 1992. Un año en la historia de Aragón, 1492. Zaragoza: Caja de Ahorros de la Inmaculada.

Tilander, Gunnar. 1956. Traducción aragonesa de la obra "In excelsis Dei thesauris", III. Lund: Hakan Ohlssons.

1958. Documento desconocido de la aljama de Zaragoza del año 1331. Stockholm.

Valdés, Juan De. 1969. Diálogo de la lengua. Edición de Juan M. Lope Blanch. Madrid: Clásicos Castalia.

VÁrvaro, Alberto. 1987. Il giudeo-spagnuolo prima dell'espulsione del 1492. Medioevo Romanzo 12: 155-171.

Zamora Vicente, Alonso. 1967. Dialectología española. Madrid: Editorial Gredos, $2^{\mathrm{a}}$ edición. 
Documentos facsímiles

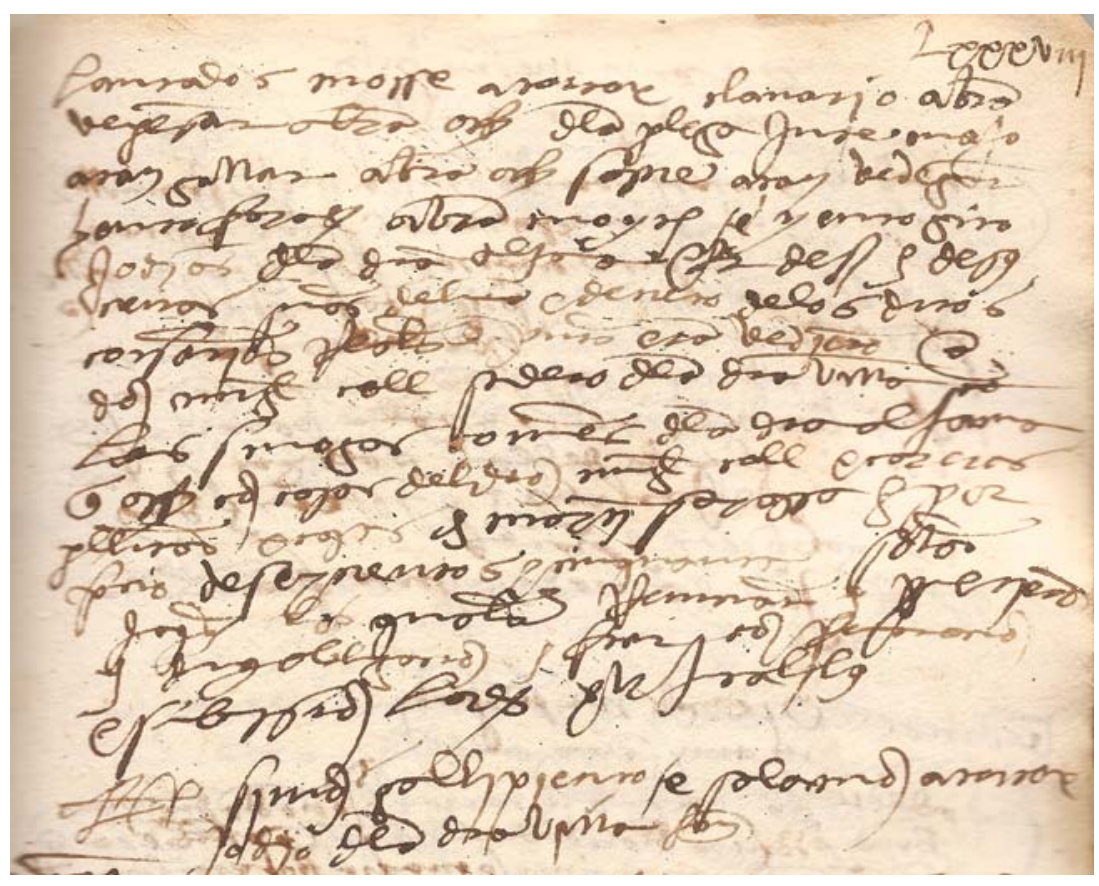

Texto I. Venta de la sinagoga de la aljama de Magallón (nota 24) 


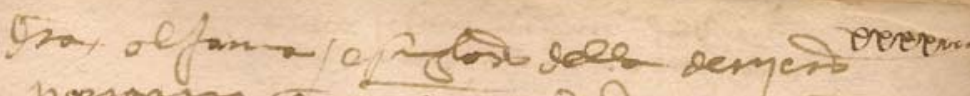

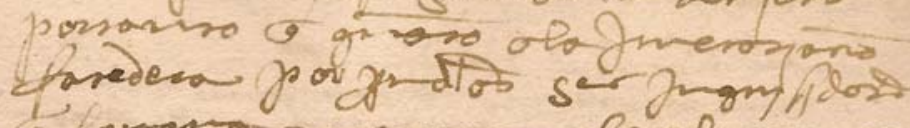

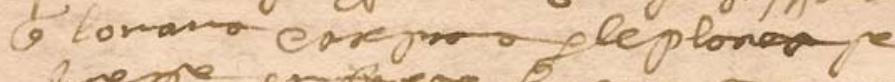

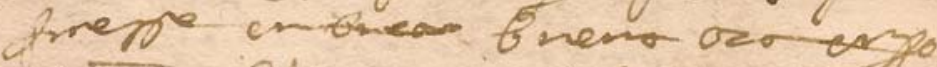

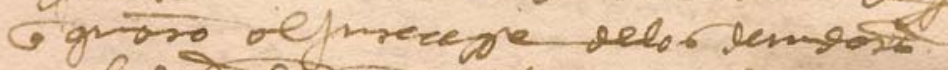

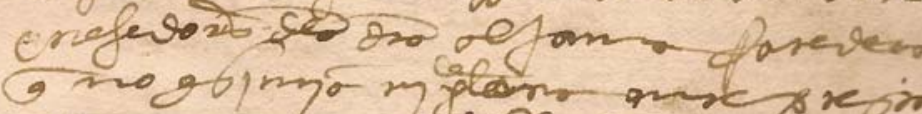

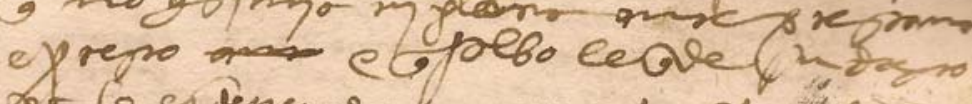

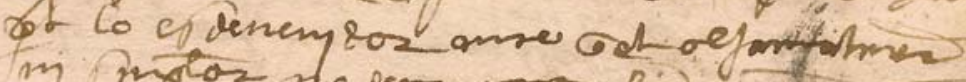

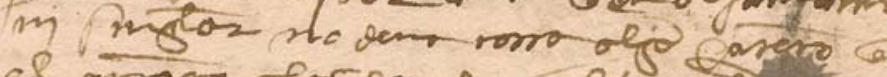
cl graro ofor semor olfande

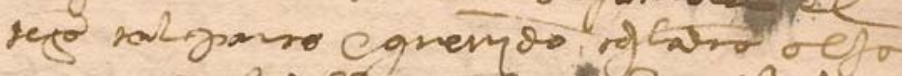

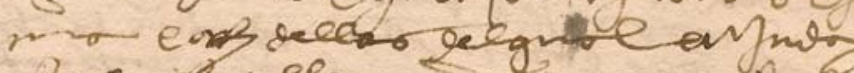

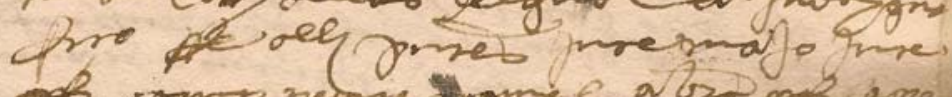

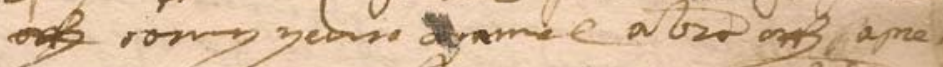

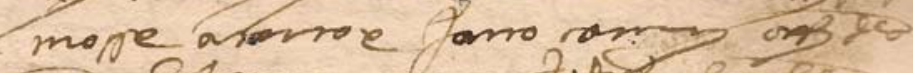

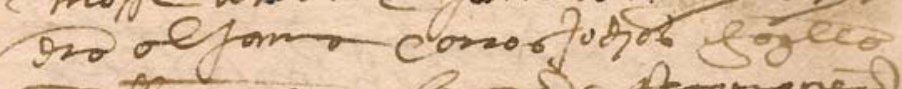

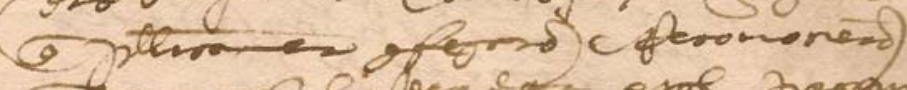
Qtizo or) labereas eroe porama

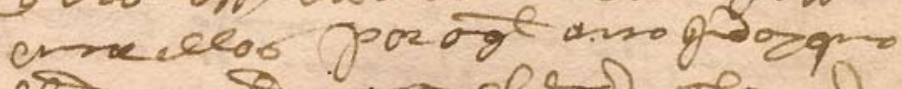

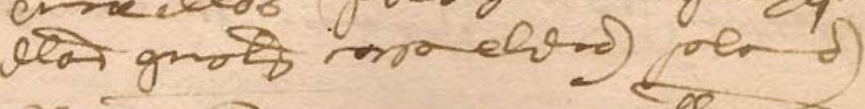
zegino por m y w sogelno

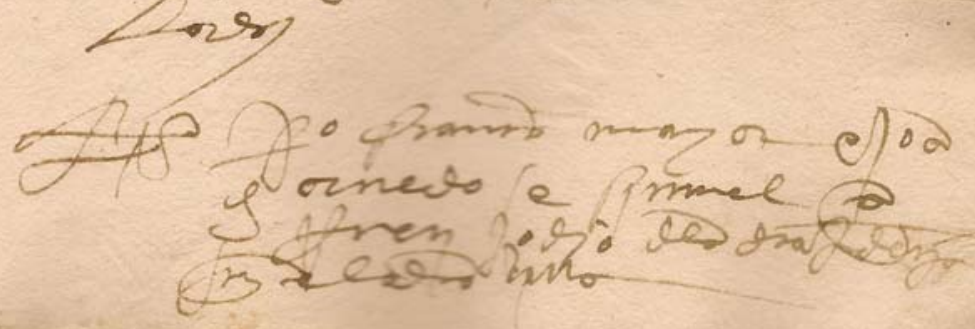

Texto II. "Salomón Atortox "en judayquo fiço fe" (nota 25) 


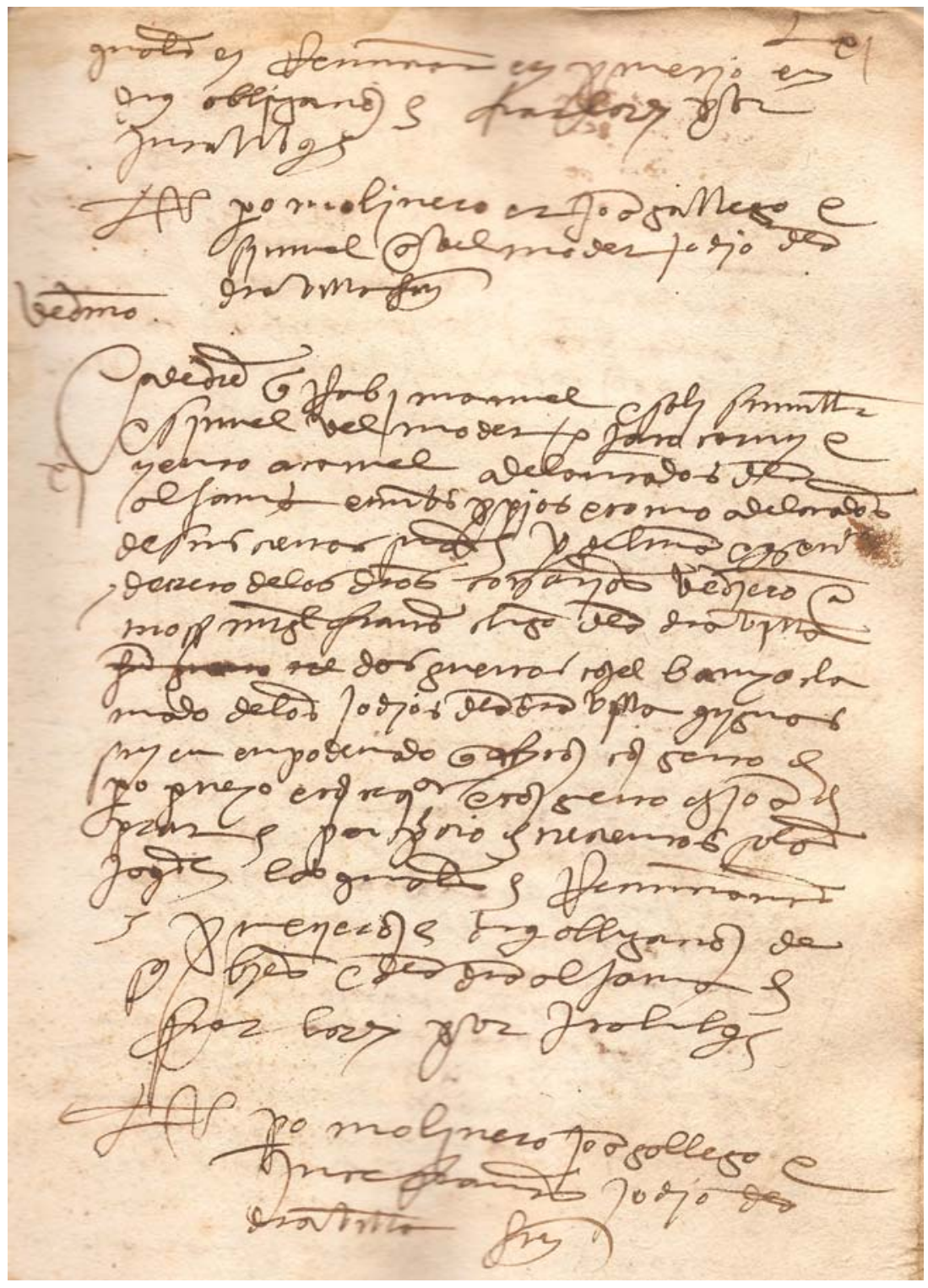

Texto III. Venta del Baño de los judíos (nota 28) 


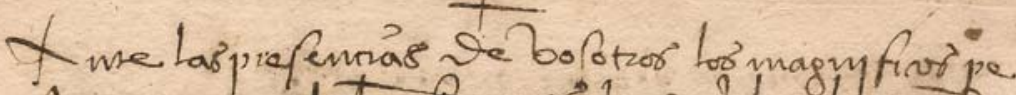

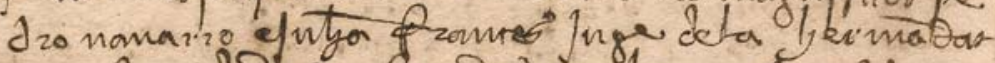

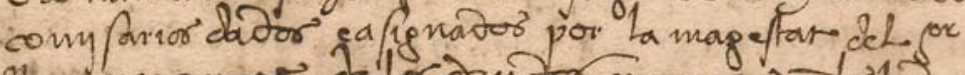

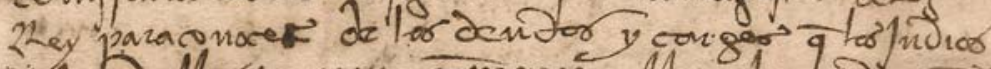

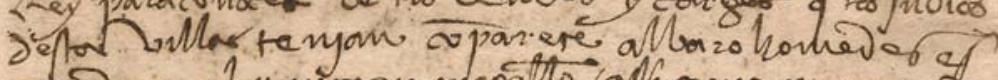

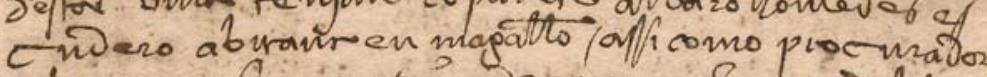
del magnyficomint m de gurcon fentror.delin gac De arganyefo com arito gneo por la mapeftrs

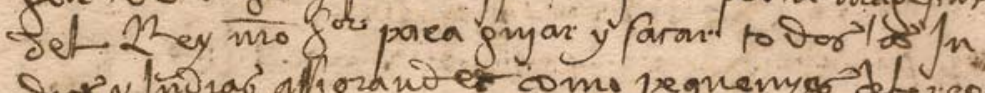

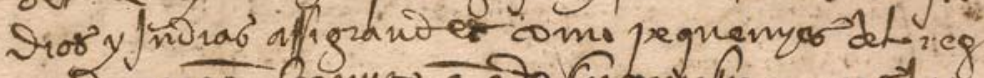

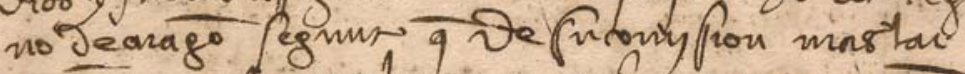
pamete confta por linuia pingfion parem eco

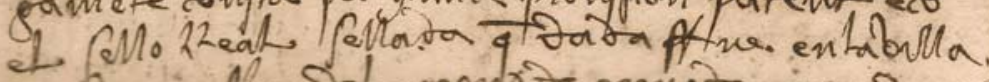

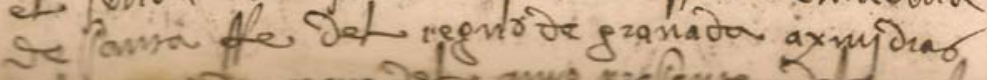

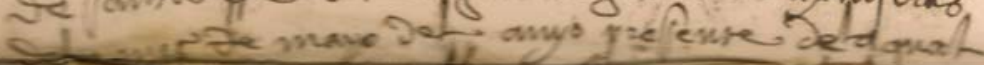
es preprow? prowad:

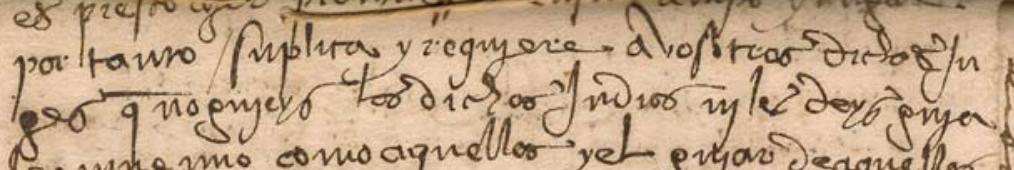
Ler minemo connoaguellos yet guyar jeagnellor ca remefo ofureat mapefrar oal dichomprin

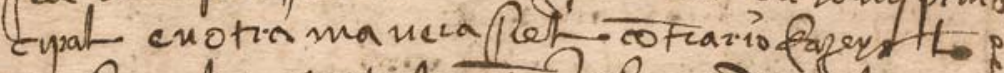

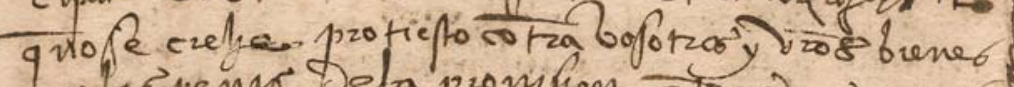
en tar penar Dela pinfion colvyjar notrab

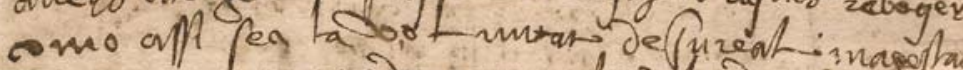

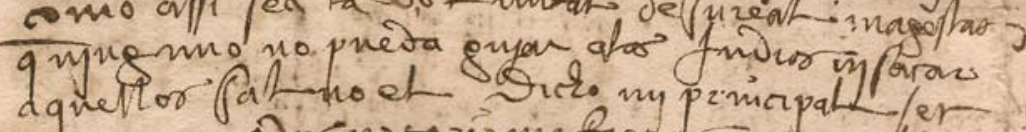

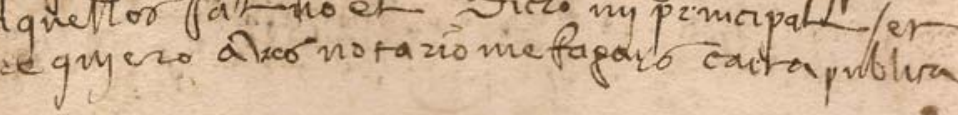

Texto IV. Litigio por la conducción de los judíos fuera de Aragón (nota 30) 